\title{
Theoretical and methodological background for sports selection and orientation in modern elite sports
}

\author{
Vladimir Platonov \\ National University of Ukraine on Physical Education and Sport, Kyiv, Ukraine
}

\section{ABSTRACT \\ Theoretical and methodological background for sports selection and orientation in modern elite sports Vladimir Platonov}

The article dwells on theoretical and methodological foundations for the identification and development of sports talents, i.e. searching for promising personalities capable of achieving high results in sports, incorporating them into an effective system of long-term training and appropriate orientation of their training based on individual potential, abilities, and inclinations. It shows that sports selection and orientation are permanent processes closely related to tasks and contents of each stage of long-term preparation. The article reveals organizational and content-related peculiarities of sports selection exemplified by the achievements of modern science and successful practices inherent to sports of the former USSR and the GDR and modern sports of the USA, China, Germany, and Australia, i.e. the countries where this issue has been and is being given the highest priority.

A set of criteria were analysed in detail, which are used in the selection and orientation process, including indicators that allow assessing the health of athletes, peculiarities of their body types, their age and sexual development, capabilities of various energy supply systems, their ability to master sports techniques and develop motor qualities, their mental peculiarities, and others. Much attention was paid to the genetic aspects of sports selection and orientation along with the importance of athletes' body types for achieving high sports results.

The relationships were shown between the selection criteria, their tasks, and the contents of each stage of long-term preparation, which is of fundamental importance for an objective assessment of an athlete's potential and rational orientation of the subsequent preparation.

The potential and inclinations of athletes in relation to the specifics of various sports can be identified towards the end of the puberty period with a reasonable certainty. Depending on their predisposition to achievements in different events, young athletes can be divided into 5 groups: sprinters, mixed type with a predisposition to sprint work, mixed type with mixed abilities, mixed type with a predisposition to long-distance or long-term work, and long-distance performers.

Keywords: identification of sports talents, sports selection, sports orientation, potential, inclinations, talent, giftedness, stages of long-term preparation of athletes.

\section{АННОТАЦИЯ \\ Теоретико-методологические основы спортивного отбора и ориентации в современном спорте высших достижений \\ Владимир Платонов}

В статье отражены теоретико-методологические основы идентификации и развития спортивных талантов, т.е. поиска перспективных людей, способных добиться высоких результатов в спорте, включения их в эффективную систему многолетней подготовки и соответствующей ориентации подготовки на основе индивидуальных задатков, способностей и склонностей. Показано, что спортивный отбор и ориентация являются перманентными процессами, тесно связанными с задачами и содержанием каждого из этапов многолетней подготовки. Раскрыты организационные и содержательные особенности спортивного отбора на основе достижений современной науки и успешной практики, характерной для спорта бывших СССР и ГДР и современного спорта США, КНР, Германии, Австралии, т.е. стран, в которых этой проблеме уделялось и уделяется первостепенное внимание.

Подробному анализу подвергнута совокупность критериев, используемых в процессе отбора и ориентации, в числе которых показатели позволяющие оценить здоровье спортсменов, особенности их конституции, возрастного и полового развития, возможности разных систем энергообеспечения, способности к освоению спортивной техники и развитию двигательных качеств, особенности психики и мн. др. Большое внимание уделено генетическим аспектам спортивного отбора и ориентации, значимости для достижения высоких спортивных результатов конституции атлетов. Показана зависимость критериев отбора с задачами и содержанием каждого из этапов многолетней подготовки, что является принципиально важным для объективной оценки перспектив спортсмена и рациональной ориентации их последующей подготовки.

Задатки и склонность спортсменов применительно к специфике разных видов спорта с достаточной достоверностью могут быть выявлены в конце пубертатного периода полового развития. В зависимости от предрасположенности к достижениям в разных видах соревнований юные спортсмены могут быть подразделены на пять групп: спринтеры, миксты с предрасположенностью к спринтерской работе, миксты со смешанными способностями, миксты с предрасположенностью к стайерской работе, стайеры.

Ключевые слова: идентификация спортивных талантов, спортивный отбор, спортивная ориентация, задатки, склонности, талант, одаренность, этапы многолетней подготовки спортсменов. 


\section{SPORTS SELECTION}

\section{AND SPORTS ORIENTATION}

The level of achievements in modern sports is so high that in order to surpass it, an athlete needs to possess a set of rare morphological and functional characteristics, a unique combination of physical and mental potential and abilities at a marginal level of development. Such combination is extremely rare. However, a natural predisposition to achievements in this or that sport will not guarantee success if selection and sports training at different stages of long-term perfection are standard, without selection criteria typical for each stage of long-term preparation and a permanent focus on development of potential inherent to a particular athlete, taking into account the peculiarities of his/her age and sexual development.

Sports selection is a process of searching for people capable of achieving high results in a specific sport and incorporating them into the system of preparation for the highest achievements.

Sports selection rests upon such concepts as "potential", "abilities", "inclinations", "aptitude", and "talent". Potential is a set of primary natural characteristics of a person, with which a person is born and which predetermine a person's development in many ways. Potential is a set of inborn anatomical and physiological features of the bodily structure, the motor apparatus, the sense organs, and neurodynamic properties of the brain, which evolve into abilities under the influence of external environment. Abilities cannot be innate. Only potential is inborn, the result of its development is abilities that cannot emerge beyond the corresponding objective activity [16]. The formation of abilities is largely determined by the inclinations that represent certain relationships between a person and activities, act as their motivational component. Without inclination, the process of developing an ability will not be effective, and, likewise, inclinations will not acquire a specific orientation without the existence of a rationally organized activity. Aptitude is a hereditary set of features for potential development of abilities, which influence the result in a particular activity. Aptitude does not guarantee success in activities but only a possibility of achieving it. Talent is a high level of abilities for a particular activity as a result of the development of aptitude. The combination of such abilities generates a product of such activities notable for a high level of perfection. The formation of talent is directly dependent on conditions of life and activities of an athlete.

Sports orientation is determining promising areas for achieving the highest sports mastery based on the study of potential, inclinations, and abilities of athletes, individual peculiarities of their skills formation. Orientation may concern the choice of a narrow sports specialization within a given sport (sprinter - long-distance runner, defender - attacking player, etc.); the definition of an individual structure of long-term training, the dynamics of workloads and the rate of achievement growth; the establishment of the leading factors of preparedness and competitive activities ca- pable of producing a decisive impact on the level of sports results of a particular athlete; the identification of means, methods, and workloads that may adversely affect the development of inclinations, suppress the individuality of an athlete, etc.

Therefore, sports selection aims to solve the problem of finding promising people that may be trained into outstanding athletes, and sports orientation is to determine the strategy and tactics of such preparation in the system of education and training.

In Western countries, the study of the issue of sports selection and orientation is carried out in the mainstream of such concepts as the "identification of talent" and the "development of talent". At the same time, the identification is understood as the process of finding children promising (gifted) for sports, and the development is understood as the process of forming abilities that ensure the realization of natural potential and the achievement of the highest sports mastery [51].

\section{RELATIONSHIP BETWEEN SELECTION AND ORIENTATION AND STAGES OF LONG-TERM PREPARATION}

Sports selection and orientation are not one-moment events at this or that stage of sports development but represent an almost uninterrupted process that covers the whole long-term preparation of an athlete. This is due to the inability to clearly identify abilities at a particular stage of age development or long-term preparation as well as a complex nature of the relationship between hereditary factors that manifest themselves as potential and acquired factors resulting from a specifically organized training. Even a very high potential to do a particular sport, which testifies to the natural aptitude of a child, serves only as a necessary background for the selection. True abilities may only be revealed in the process of education and upbringing and are the result of a complex dialectical unity - of the innate and acquired, the biological and social. This predetermines the organic relationship between selection and orientation and stages of long-term preparation, where each stage solves its specific tasks (Table 1).

Each stage of selection is distinguished by its own methods and criteria, the accuracy of assessments and the finality of conclusions. If during the primary selection genetically determined anthropometric, morphological and functional properties of those in the training process, characterized by small variability under the influence of training, play the lead role, then at the final - fifth - stage, these indicators are almost disregarded, and the main attention is focused at the level of sports achievements, the amount and nature of the previous work loads, mental peculiarities of athletes, their health, social status, and motivation to continue doing sports $[8,80]$.

During the primary and preliminary selection the assessments are mostly of a presumptive and recommendatory nature; at later stages, they become more precise and 
TABLE 1 - Relationship between selection of athletes and stages of their long-term preparation [9]

\begin{tabular}{l|l|l}
\multicolumn{1}{c|}{ Stage } & \multicolumn{1}{c|}{ Sports selection } & \multicolumn{1}{c}{ Task } \\
Primary & To determine worthwhileness of practicing a specific sport & Initial (2-3 years) \\
\hline Preliminary & $\begin{array}{l}\text { To assess the available potential and abilities for effective } \\
\text { sports perfection }\end{array}$ & Preliminary basic (2-3 years) \\
\hline Intermediate & $\begin{array}{l}\text { To assess the capabilities for achieving a high level of skill } \\
\text { in specific disciplines, enduring significant training and } \\
\text { competitive loads }\end{array}$ & Specialized basic (2-3 years) \\
\hline Main & $\begin{array}{l}\text { To assess the prospects for achieving high-class results at } \\
\text { the international level, the reserves for the increase of sports } \\
\text { achievements }\end{array}$ & $\begin{array}{l}\text { Preparation for the highest achievements (2-3 years) } \\
\text { Maximum realization of individual achievements } \\
\text { (from 1-2 to 7-8 years and more) }\end{array}$ \\
\hline Final & $\begin{array}{l}\text { To assess the ability for maintaining the achieved results } \\
\text { and their improvement. To determine the worthwhileness of } \\
\text { continuing the sports career. }\end{array}$ & $\begin{array}{l}\text { Maintain a high level of skills. Gradual decline } \\
\text { of results (the duration of each stage is strictly } \\
\text { individual) }\end{array}$ \\
\hline
\end{tabular}

specific. The basis for such assessments is the experience of working with an athlete accumulated by his/her trainer, doctor, and other specialists. This information together with the results of complex examinations form basis for more substantiated conclusions.

At each stage of the sports selection, not only the worthwhileness of an athlete's further preparation is determined, but a detailed assessment of his/her potential and abilities, strengths and weaknesses of his/her technical and tactical skills, functional preparedness, the level of development of his/her motor qualities, mental peculiarities is performed, the previous stage of his/her training - its orientation, size, and nature of workloads, their appropriateness to the individual characteristics of the athlete, etc. - is carried out. All these data create grounds for the orientation of an athlete's preparation at the next stage of his long-term perfection. In this way, the stages of sports selection are organically linked to sports orientation. We shall provide the general insight into the tasks and criteria of each stage of the long-term selection.

It is typical for effective systems of selection and longterm preparation of athletes to eliminate athletes who cannot reach the top level at each stage of selection. Such athletes are recommended either to choose specialization in other sports or to continue their sports activities at other levels of sport (mass, amateur, municipal, regional, etc.) (Figure 1). The exclusion from the system of elite sports of unpromising athletes is considered an important factor in optimization of the process of training promising athletes, enabling the form of homogeneous groups, creation of the material and organizational conditions, psychological atmosphere necessary for effective preparation.

As practice of the recent years has shown, such an approach not only allows to improve the quality of preparation of the most promising athletes, but also becomes one of the effective directions for finding promising athletes among those who have been actively engaged in this or that sport for many years, but have not achieved signifi- cant success. This approach encompasses athletes who possess 5-10 years of experience in sports and are usually 15-20 years old. Such approach is quite effectively exercised in Australia; in other countries, attention is only drawn to the prospects of development of such direction.

Primary selection. The task is to determine the worthwhileness of practicing a specific sport for a child. The main criteria are the age proper to engage into training; the absence of serious health abnormalities and liabilities to diseases that impede doing sports; the conformity of a body type with the requirements of the sport; the correspondence of the level of motor potential to the requirements of the sport.

Preliminary selection. The task is to assess the available potential and abilities of athletes for effective sports perfection. The main criteria are the absence of health abnormalities; the conformity of the body build, structure and potential of the muscular system, energy potential, analyser systems and motor abilities with the requirements of the sport; propensity of the main functional systems and mechanisms to adaptational changes under the influence of training.

Intermediate selection. The task is to assess the capabilities of athletes to achieve a high level of skill in specific disciplines and types of competitions. The main criteria are the conformity of the body build with the capability of gaining results at the international level; the stable motivation to deliver positive results; the absence of health abnormalities that may impede successful sports performance; the mental and functional readiness to endure severe workloads; the reserves for further adaptation of the functional systems and mechanisms, the increase of motor qualities, the improvement of the most important elements in techniques, various components of tactical and psychological preparedness.

Main selection. The task is to assess the prospects for an athlete to achieve high-class results at the international level. The main criteria are the degree of motivation to reach the top level skill and the absence of any health 


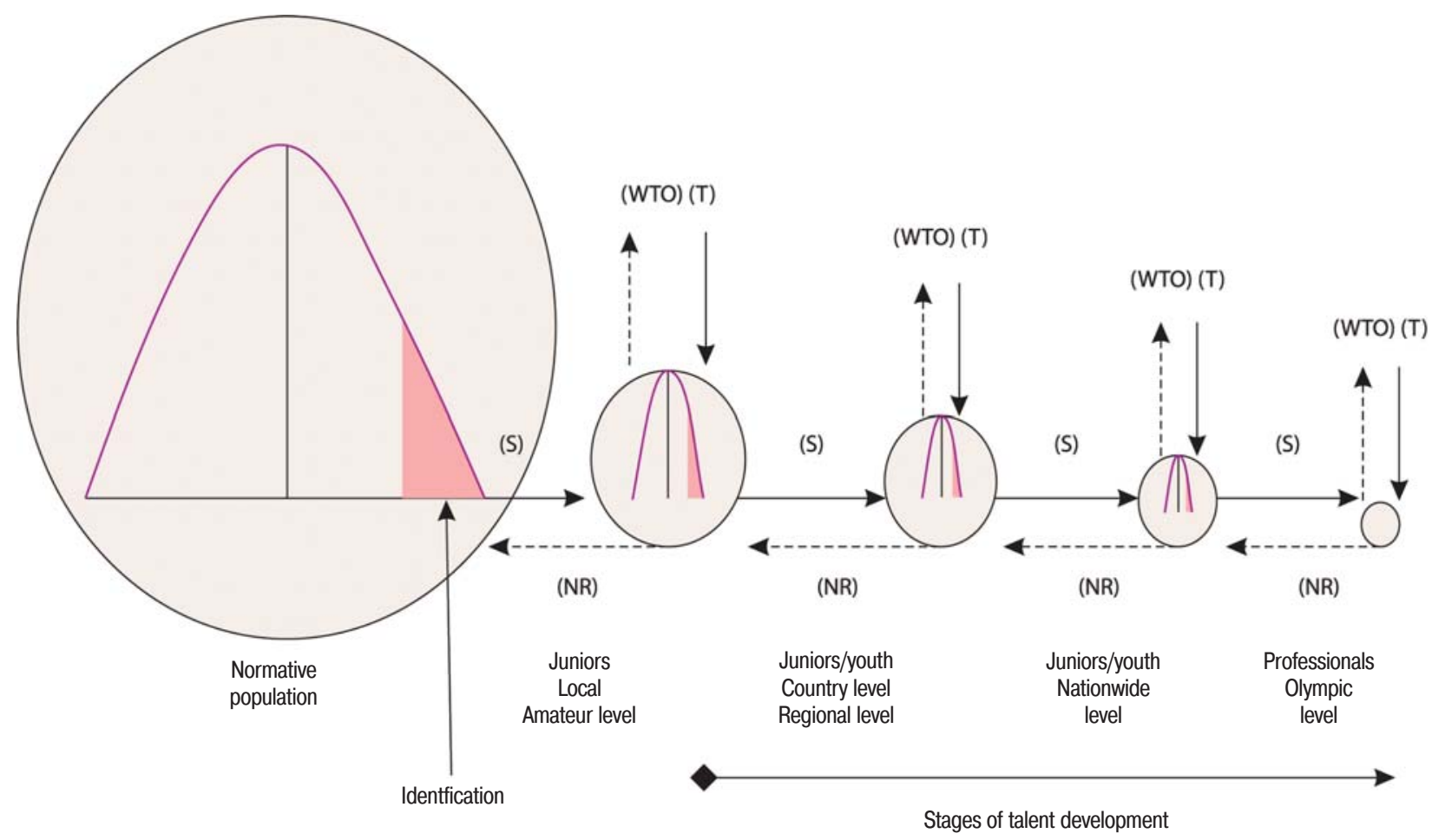

FIGURE 1 - The conceptual model of identification and development of talents in the Olympic sports:

S - selection, NR - not retained, T - transition to the next stage, WTO - removal [27]

obstructions; the mental and functional preparedness to endure training and competitive loads, including those in complicated conditions - an unusual or unfavourable climate, a change of time zones, in conditions of heat, middle altitudes, psychological tension of important competitions, etc.; the ability to realize the attained level of preparedness in conditions of the intense competition during major events in full and to set personal records in such competitions; the ability to perceive a competitive situation adequately, to vary the components of technical, tactical, and other forms of preparedness.

Final selection. The task is to assess the worthwhileness for an athlete to continue doing sports and forecast his/her ability to maintain a high level of skills. The main criteria are the presence of motivation and the absence of health conditions impeding the preservation of skills; the age of an athlete and its compliance with the age limits optimal for the achievement of the highest results in the types of competitions chosen as specialization as well as the time period when skills are maintained at a high level; the presence of body reserve capacities necessary to maintain the level of preparation; the social and financial status facilitating the advancement of the sports career.

\section{ORGANIZATIONAL AND CONCEPTUAL FEATURES OF SPORTS SELECTION}

The continuing growth of achievements in modern sports is closely related to the increased requirements to the anthropometric, morphological, functional, and mental characteristics of athletes, which reduces the number of children capable of achieving high results in different sports and increases the importance of sports selection. The above may be illustrated by simple examples. For instance, the fundamental studies conducted by N. Zh. Bulgakova some time ago $[3,4]$ with the participation of a large number of highly qualified swimmers showed that an average height of male swimmers specializing in $100 \mathrm{~m}$ freestyle was $180 \mathrm{~cm}, 400 \mathrm{~m}-177.5 \mathrm{~cm}$, and $1500 \mathrm{~m}-174 \mathrm{~cm}$. The height of swimmers specializing in breaststroke swimming averaged $175 \mathrm{~cm}$, backstroke swimming - $183 \mathrm{~cm}$, butterfly stroke swimming $-176 \mathrm{~cm}$. That is, the highest results were achieved by swimmers mainly of a medium height, and in some types of events - of a height somewhat above average. The body mass indexes were average as well. The swimmers who specialized in $100 \mathrm{~m}$ freestyle weighted $75 \mathrm{~kg}, 400$ m - 67 kg, 1500 m - 65 kg; breaststroke - 76,5 kg; backstroke - 69 kg; butterfly stroke $73 \mathrm{~kg}$.

Nowadays, the highest results are delivered by swimmers with quite different parameters. Most swimmers (more than 90\%) who have achieved high results in swimming at distances of 100 and $200 \mathrm{~m}$ are notable for their tall height $(190-200 \mathrm{~cm})$ and large body mass of 80$100 \mathrm{~kg}$. For example, the height of Gary Hall Jr. is $198 \mathrm{~cm}$, his weight is $94 \mathrm{~kg}$; Alexander Popov has $200 \mathrm{~cm}$ and $89 \mathrm{~kg}$; Alain Bernard - $196 \mathrm{~cm}$ and 84 kg; Milorad Čavić - $198 \mathrm{~cm}$ and 98 kg; Aaron Peirsol - 185 cm and 90 kg; Brenton Rickard - $194 \mathrm{~cm}$ and $92 \mathrm{~kg}$; Matt Grevers - $203 \mathrm{~cm}$ and 104 kg; 
Michael Phelps - $193 \mathrm{~cm}$ and 88 kg; Tom Dolan - $201 \mathrm{~cm}$ and 90 kg; Ian Crocker - 196 cm and 88 kg; Matt Targett $198 \mathrm{~cm}$ and 98 kg; Ryan Lochte - $188 \mathrm{~cm}$ and 87 kg; César Cielo Filho $-196 \mathrm{~cm}$ and $80 \mathrm{~kg}$.

Even more surprising were the changes that affected swimmers specializing in freestyle swimming at distances of 400 and $1500 \mathrm{~m}$. According to conventional beliefs, these swimmers possess significantly lower height and lower body weight and slimmer physique in comparison to sprinters. For example, the height and weight of double Olympic champions in freestyle swimming at distances of 400 and 1500 m Michael Barton (1968) and Brian Goodell (1976) were $171 \mathrm{~cm} / 65 \mathrm{~kg}$ and $173 \mathrm{~cm} / 67 \mathrm{~kg}$ respectively. The characteristics of the current strongest swimmers are totally different: Kieren Perkins - $192 \mathrm{~cm}$ and 90 kg; Grant Hackett - $197 \mathrm{~cm}$ and 96 kg; lan Thorpe $196 \mathrm{~cm}$ and $104 \mathrm{~kg}$; Paul Biedermann - $193 \mathrm{~cm}$ and $93 \mathrm{~kg}$; Ryan Cochrane - $192 \mathrm{~cm}$ and 80 kg; Sun Yang - $198 \mathrm{~cm}$ and $81 \mathrm{~kg}$. In contrast to the above, the height and weight indexes - $183 \mathrm{~cm}$ and $74 \mathrm{~kg}$ - of the 2011 world champion in the $400 \mathrm{~m}$ freestyle, Korean swimmer Park Tae-Hwan are perceived as an exception.

Similar changes occurred in many other sports. In the 1960s and 1970s, most outstanding athletes specializing in rowing were $180-190 \mathrm{~cm}$ tall and weighed $80-90 \mathrm{~kg}$. There are very few modern outstanding rowers with such body indexes. The majority are 190-205 cm tall and 90-110 kg in body weight: Olaf Tufte - $201 \mathrm{~cm}$ and 99 kg, Tõnu Endrekson - $198 \mathrm{~cm}$ and $106 \mathrm{~kg}$, Malcolm Howard - $198 \mathrm{~cm}$ and 106 kg, Andrew Byrnes - $201 \mathrm{~cm}$ and 93 kg, Alexey Svirin $203 \mathrm{~cm}$ and $103 \mathrm{~kg}$.

Significant changes occurred in women's gymnastics. However, the tendency here is the opposite: the height and weight of the most successful female athletes is much lower than that of their predecessors - top world performers of the 1960s and 1970s. The overwhelming majority of female athletes who were successful at the Olympic Games and World Championships in recent years (2000-2012) are distinguished by the low stature (140-150 cm) and small body weight (35-45 kg). Their outstanding predecessors (Larysa Latynina, Polina Astakhova, Věra Čáslavská, Natalia Kuchinskaya, Ludmilla Tourishheva, etc.) had a much larger body mass and height $-150-165 \mathrm{~cm}$ and $50-60 \mathrm{~kg}$.

Naturally, the body indexes of modern athletes went far beyond the average. According to recent studies, the average height for men is $175 \mathrm{~cm}$, for women $-170 \mathrm{~cm}$. It is clear children who will have the height typical of modern swimmers, rowers, sprinters, or top gymnasts in the future are significantly less likely to be selected than it was $40-50$ years ago. For such medal-rich sports as swimming, rowing, a significant part of track and field disciplines, etc., the situation is even more complicated by the fact that tall athletes are in high demand in many game sports, in particular, in handball, volleyball, and not to mention, basketball.

However, body height and weight are only the simplest and most obvious indicators that determine the predispo- sition of children to sports. There are many other indicators that reflect peculiarities of the body structure and capabilities of the most important functional systems that are significant in sports selection. For instance, the outstanding American swimmer Michael Phelps, with a height of $193 \mathrm{~cm}$ and a body weight of $88 \mathrm{~kg}$, has an untypical body build: big feet (shoe size - 47), a long and streamlined trunk and relatively short legs, a low centre of gravity, long arms and hands - his arm span is $6 \mathrm{~cm}$ longer than his body length. This type of body build ensures significant advantages in swimming, academic rowing, creating prerequisites for the formation of effective techniques with a greater amplitude of working movements. On the contrary, long legs, a relatively short trunk, and a high centre of gravity are typical for runners at different distances, providing a rational body position and a greater length of steps.

All this significantly reduces the chances of identifying promising children and requires an extension of the search cohort. As aptly noted by Forbes Carlile [26], the only way out of this situation is mass training in the basics of sports at primary schools as the most important prerequisite for selecting children for the primary stage of long-term perfection.

Equally important for the modern selection system is the problem of exclusion of young athletes who do not possess real potential for achieving high results from elite sports. The optimal statistics in this question differs fundamentally from the one that was actual 40-50 years ago (Figure 2).

Starting from the third stage of long-term preparation, teenagers who have no obvious prospects of delivering international results should be eliminated from the system of elite sports. This may be justified by two reasons. The first one is that preparation at this stage already requires 1-2 daily training sessions with a total duration of 3-4 hours. And the organization of such work with a large number of trainees, associated with non-productive material expenses, excessive use of sports facilities, complicates the work with truly talented young athletes. The second one is the considerable amount of effort and time invested by young athletes with limited prospects inevitably prevents them from receiving proper education and self-fulfilment in other spheres of activity, to which they are more likely to be inclined. Such teenagers should not be excluded from sports. They can be recommended to test their abilities in other sports activities or to continue their training in mass school sports.

An important point of the multi-stage selection system in the process of long-term preparation is the focus of the entire system on the inclusion of prospective athletes into national teams to participate in the largest competitions - the Olympic Games and World Championships. Currently, this point is well realized by the U.S. specialists who have formed, for example, a fairly comprehensive order of stage-by-stage selection of promising athletes in swimming through the system of zonal qualifying camps and 


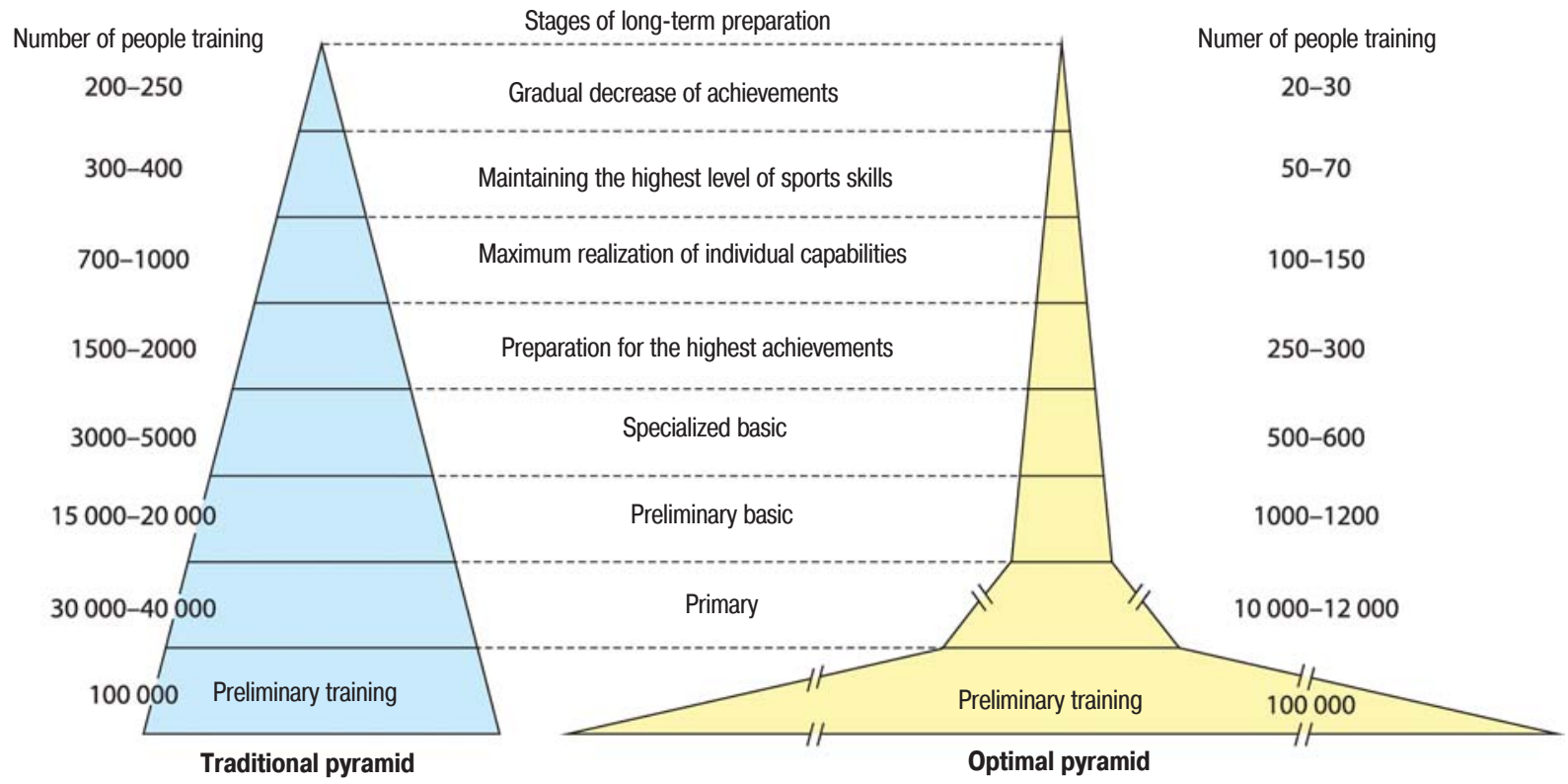

FIGURE 2 - The traditional and modern approaches to the formation of a sports reserve and stage-by-stage selection of athletes in the system of long-term preparation

competitions of various levels. To illustrate this, Figure 3 depicts the scheme of a multi-stage selection system of swimmers for the Olympic team.

Equally effective in the U.S.A. are the selection activities in a number of other sports. For example, back in the early 1990s, a program of identifying and developing sports talents (TOPs) in women's artistic gymnastics at various stages of long-term perfection was formed (Figure 4).

The goal of the program was the identification of young talented gymnasts by testing their anthropometric indexes, physical qualities and professional abilities and the development of methods to improve their skills with a focus on participation in the Olympic Games. It is notable that this program, launched in 1992, was largely based on the experience of training gymnasts in the countries of the already dissolved bloc of Eastern European countries (the USSR, Romania, Bulgaria) and was viewed as the one capable of competition with the training systems of gymnasts in those countries [71].

In the process of program implementation, the results of physiological studies were discarded as such containing questionable and contradictory information. The same happened with nonspecific tests aimed at the assessment of physical fitness levels - push-ups, pull-ups, long jump, medicine ball throws, one-leg balances, etc. [49]. The main part of the testing program consisted of 9 special tests designed on the material of motor actions typical of artistic gymnastics [71].
FIGURE 3 - The system for the stage-bystage selection of the U.S. swimmers for the Olympic team (American Swimming Coaches Association)

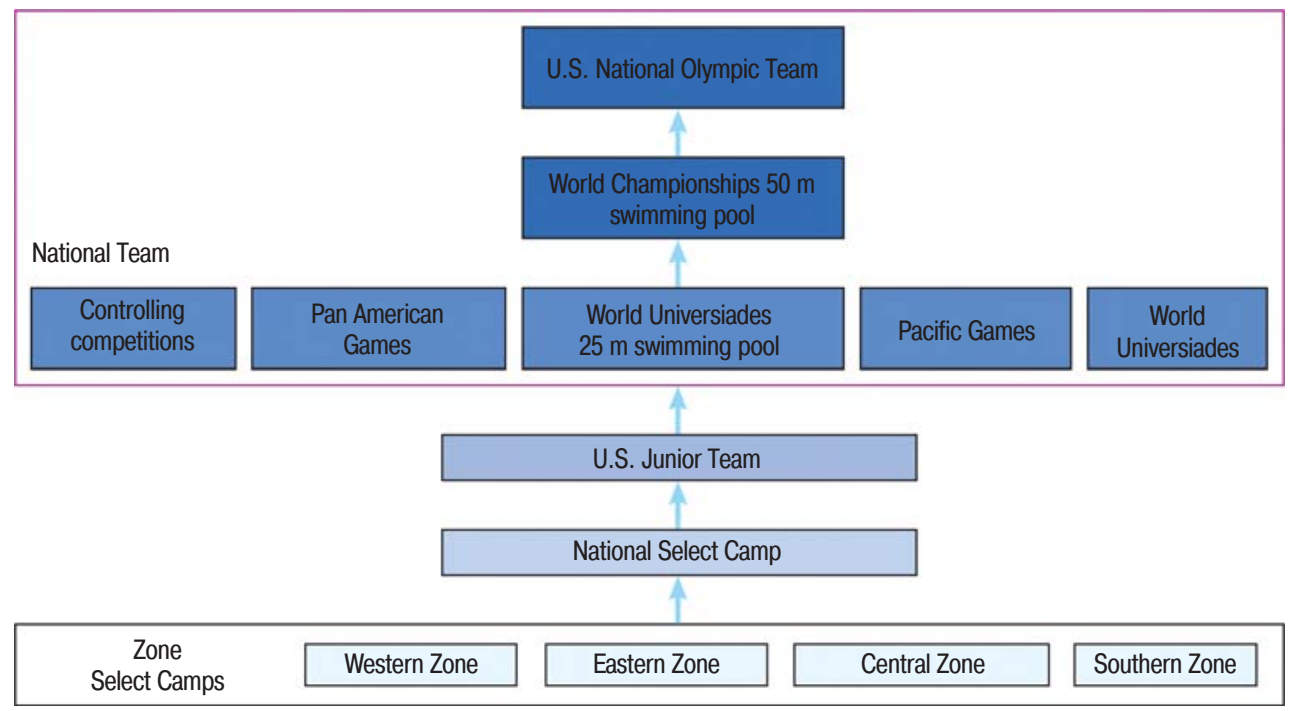




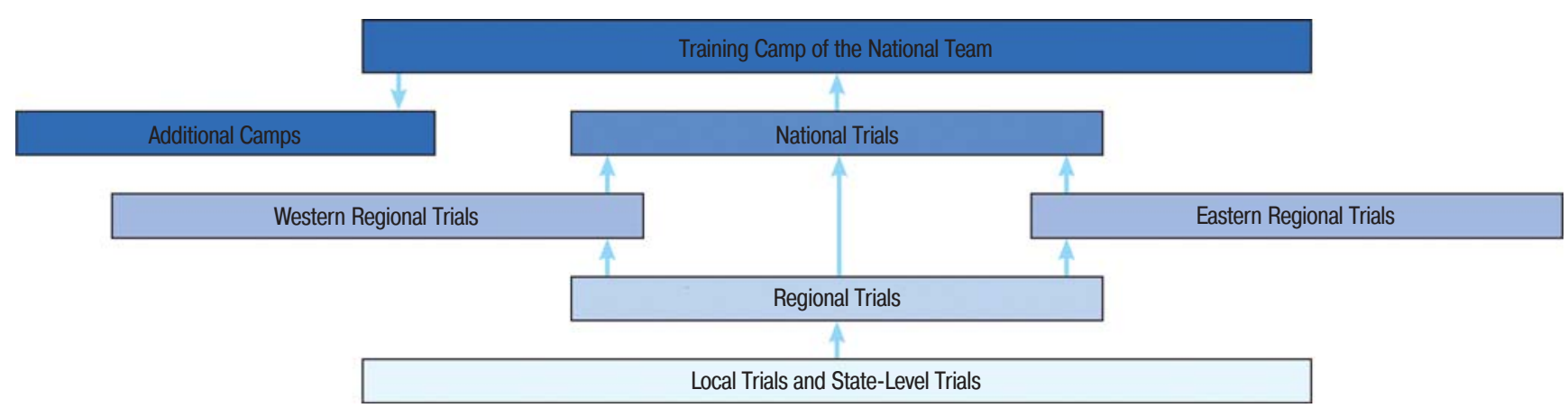

FIGURE 4 - The structure of multistage testing in the program of talent identification and development in women's artistic gymnastics in the USA [70]

In 20 years of the program existence, 25 thousand gymnasts underwent testing, of which 1338 persons were recognized as capable of achieving high sports results. The training system for those gymnasts was based on the following principal guidelines:

- versatile multi-stage testing based on the material of the main anthropometric indexes and special motor actions;

- optimization of the system of long-term preparation based on the patterns of age development and peculiarities of the sports mastery development;

- rational periodization of annual preparation, ensuring an optimal combination of the training process and competitive activities, preventing from an excessively rich sports calendar;

- prioritized attention to the prevention of sports injuries in all directions: optimization of work and rest balance, selection of training means and methods of their use, improvement of special sports surfacing, apparatuses and machines, landing pits, trampolines, etc. [70].

Much attention is drawn to the further fate of athletes who have completed training for several years, but who have no prospects for success in this sport due to lack of necessary abilities. It is shown that girls who are in this position are extremely strong, flexible, highly coordinated, accurate, collected, motivated and can achieve high results in ski acrobatics, pole vaulting, weightlifting, wrestling, synchronized swimming and some other sports. Naturally, it is recommended that such athletes go to classes with the kind they are more predisposed to achieve.

Such an approach is not new, it was amply used back in the former GDR, a country with a population of 16 million, where the human resource problem was acute. However, at present this approach is exercised in a country, where the population is 20 times larger.

The implementation of this program made the U.S. gymnasts the leaders of the world gymnastics. It is enough to note that at the Games of the 2008 Olympiad, the gymnasts of the USA won two gold, five silver, and one bronze medal, having outperformed the gymnasts of the PRC (6 medals, including 2 gold medals). At the 2012 Games of the Olympiad in London, six medals (of which 3 gold medals) were gained by the American gymnasts. Both in Beijing and in London, the gymnasts of the USA gained the most prestigious gold medals in the all-round competition (Anastasia Liukin, Gabrielle Douglas). At the 2016 Games of the Olympiad in Rio de Janeiro, the superiority of the American female gymnasts was overwhelming - four out of six gold medals and the same number of silver medals. For comparison, we should mention that before the implementation of this program, the American gymnasts were content with only one bronze medal at the 1988 Games of the Olympiad.

By the way, American specialists revealed an interesting connection between the place of residence of children and the effectiveness of their selection and training. They showed that the largest number of top-class athletes, entering professional clubs in the most popular sports baseball, American football, basketball, golf, and hockey -originated from small towns with a population of 50 to 100 thousand. Only $1 \%$ of the American population inhabits such cities, but it is these cities that raise $17 \%$ outstanding athletes. Ten per cent of the population lives in large cities - more than 5 million people. However, they supply not more than $1-2 \%$ of athletes to the strongest clubs. The borderline is the cities with a population of more than 500 thousand people. As the population grows, the negative ratio between the size of the cities and the effectiveness of preparation of the sports reserve increases. On the contrary, the decrease in the population leads to an increase in the effectiveness of training promising athletes - up to the range of 50-100 thousand people. The reasons for this situation are not given, but they are clear without any serious analysis. As for very small cities, their outcome with regard to the preparation of top-class athletes is also low, which is explained by the insufficient facilities and resources, the inability to establish a system of children's competitions, the lack of qualified coaches, etc. [29].

A strict system of selection of promising athletes is being implemented in the PRC in its organic relationship to the process of their long-term training. Activities of the Chinese methodology professionals are practically the same as those carried out in the 1960s-1980s in the USSR and are realized on the basis of the USSR experience. What is 


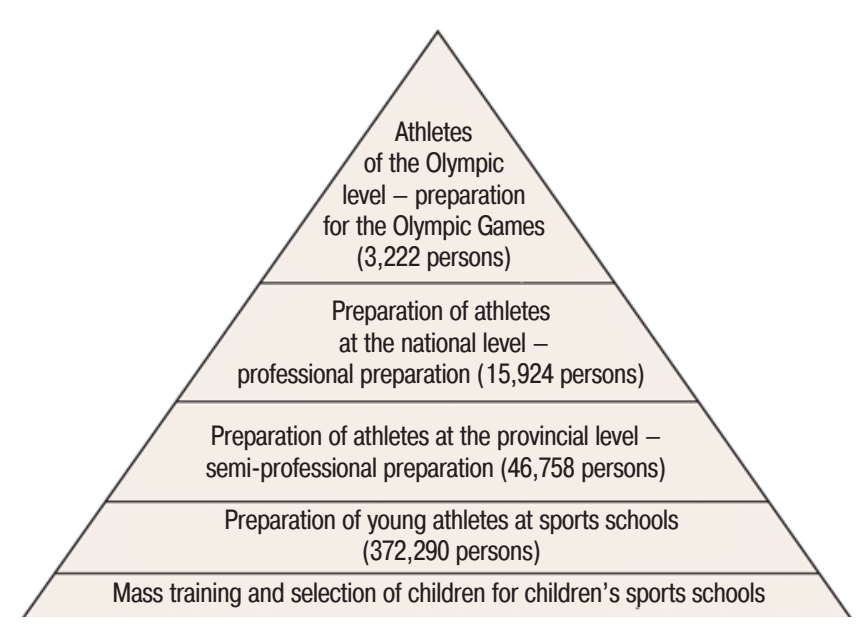

FIGURE 5 - Five levels of the Olympic training system in China and the number of athletes at each level illustrated with the data of the pre-Olympic year of 2007 [45]

different about it is that due to the rigid administrative system of management, the size of China, the interest of local administrative bodies, huge financial capacities, the whole system of selection and long-term preparation has acquired not only huge dimensions but also a strict structure and manageability at each of the five levels ( $\mathrm{Fi}$ gure 5).

At the first level are the children aged 6-10 years old involved in learning the basics of a certain sport and part of the initial selection system. Children who have been identified as having certain potential for development in a particular sport are enrolled in children's sports schools and find themselves on the second level of the pyramid.

The second level presupposes a quite intensive preparation of children for several years (up to 12-14 years of age depending on a sport). Training sessions are run 4-5 times a week for 3 hours. Alongside with the preparation at children's sports schools, the tasks of selecting the most talented children for preparation at the third level are also being solved.

The third (semi-professional) level presupposes the training of adolescents, girls and boys between the ages of 12-14 and 15-17. At this level, there is a relatively small number of children trained in children's sports schools, about $12 \%$ Training is carried out in provincial and urban specialized schools, in which the entire regime is subordinated to the task of full-fledged sports development. Training sessions are held twice a day for 4-5 hours 5-6 times a week. Special meals are organized in schools, there is a corresponding material base, medical support, qualified trainers.

After 3-4 years of preparation at the third level, the most talented athletes (about one third of them) are upgraded to the fourth (professional) level. They receive the status of national athletes and are included into the system of preparation for the highest achievements. At this level, training loads are constantly growing, athletes participate in major competitions, including international ones. Prepa- ration implies 4-6 hours of daily training sessions 5-6 times a week at schools of the highest sportsmanship (professional training centres).

The highest (fifth) level of the pyramid is the Olympic athletes, among them one in five is an athlete of the national level. In particular, 3222 athletes were preparing for the 2008 Games of the XXIX Olympiad in Beijing - almost 2.5 times as more than the number (1316) of athletes preparing for the 2004 Games of the XXVIII Olympiad. This led to an increase in the team composition. If in previous years China had two national teams - the main and reserve teams, then during preparation for the 2008 Games in Beijing, China had three (the main, youth, and reserve national teams). The number of athletes in the main national team also increased. This was done to maximize the internal competition in each sport for the right to enter the Olympic team.

A huge number of children trained at children's sports and specialized schools in China's provinces make up the core of the system of all-China support for elite sports. The main stimulus for young athletes of the second and third levels is the opportunity to become part of national and, later on, Olympic athletes. However, only about 5\% of trainees of children's sports schools reach the fourth and fifth levels of the pyramid. In the opinion of the Chinese experts themselves, this system is based on the harshest "natural selection" that blows up dreams of $95 \%$ of students of more than 3,000 children's sports schools operating in China [30].

A well-thought model of the stage-by-stage selection of athletes and the organization of their long-term preparation was created in Germany. The work is carried out at the federal level to identify talented children and set up their training during the first 5-6 years. After this, selected promising athletes are included into the harmonious multilevel system of long-term perfection (Figures 6, 7).

The overall organizational and managerial model of selection develops in different sports. For example, a multistage selection system and long-term preparation of handball players was developed in handball - a sport exceptionally popular in Germany (Figure 8).

A rather effective search system for prospective athletes was created in Australia (Figure 9). Testing takes place at three levels:

- in the system of school sports - basic anthropometric indexes are assessed;

- in the system of reserve sports - an in-depth study of the energy supply systems with the use of step ergometric tests complements the assessment of basic motor abilities and anthropometric data;

- in the system of elite sports - an aptitude to achievements in a specific sport is discovered on the basis of an in-depth study of motor abilities and capabilities for their energy supply.

At the first level, testing is carried out by school teachers, who may have various attitudes to such activities. 


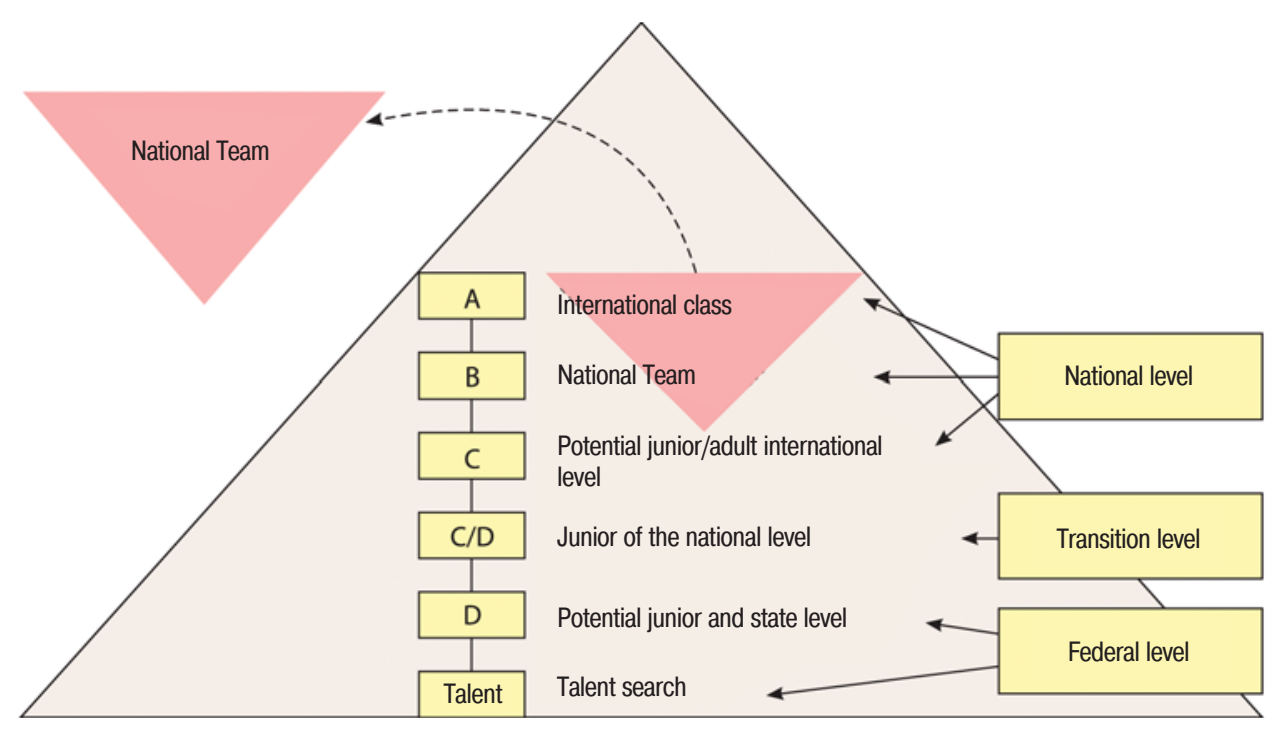

FIGURE 6 - Categories of athletes in the system of elite sports in Germany
Due to this, and also because of the inconsistency and ambiguity of test results obtained in childhood, this stage of selection provides only the most general perceptions on children's potential, the main attention is paid to the results obtained at the second and third levels, when it is already possible to determine clearly the most relevant specialization for an athlete, provide recommendations for the training process, taking into account his/her talents and abilities. It is namely testing at the second and third levels with the participation of athletes aged 14-16 and older that seriously impacts both the effectiveness of the athletes' selection, their orientation towards specialization in certain types of competitions, the content of subsequent preparation, which prevents from excessive training and aims at demonstrating the highest results in the optimal age zone [41].

A similar approach to the selection of promising athletes and orientation of their training is practiced in Great Britain [79].

The analysis of the peculiarities of the identification systems of promising children clearly reveals a tendency to focus exclusively on criteria based on various anthropometric, morphological, and physiological indexes. This is largely due to the unilateral development of sports science with prevailing biological research that demonstrates the connection of many indexes with achievements in different sports as well as to the impossibility or complexity of using other criteria related to the mental sphere, social conditions, etc. when
FIGURE 7 - Organizational and managerial model of selection of promising athletes and organization of their preparation at various stages of long-term perfection in Germany:

GLT - basic training; ABT - in-depth training; AST - training for the highest achievements; HLT - elite athletes training.

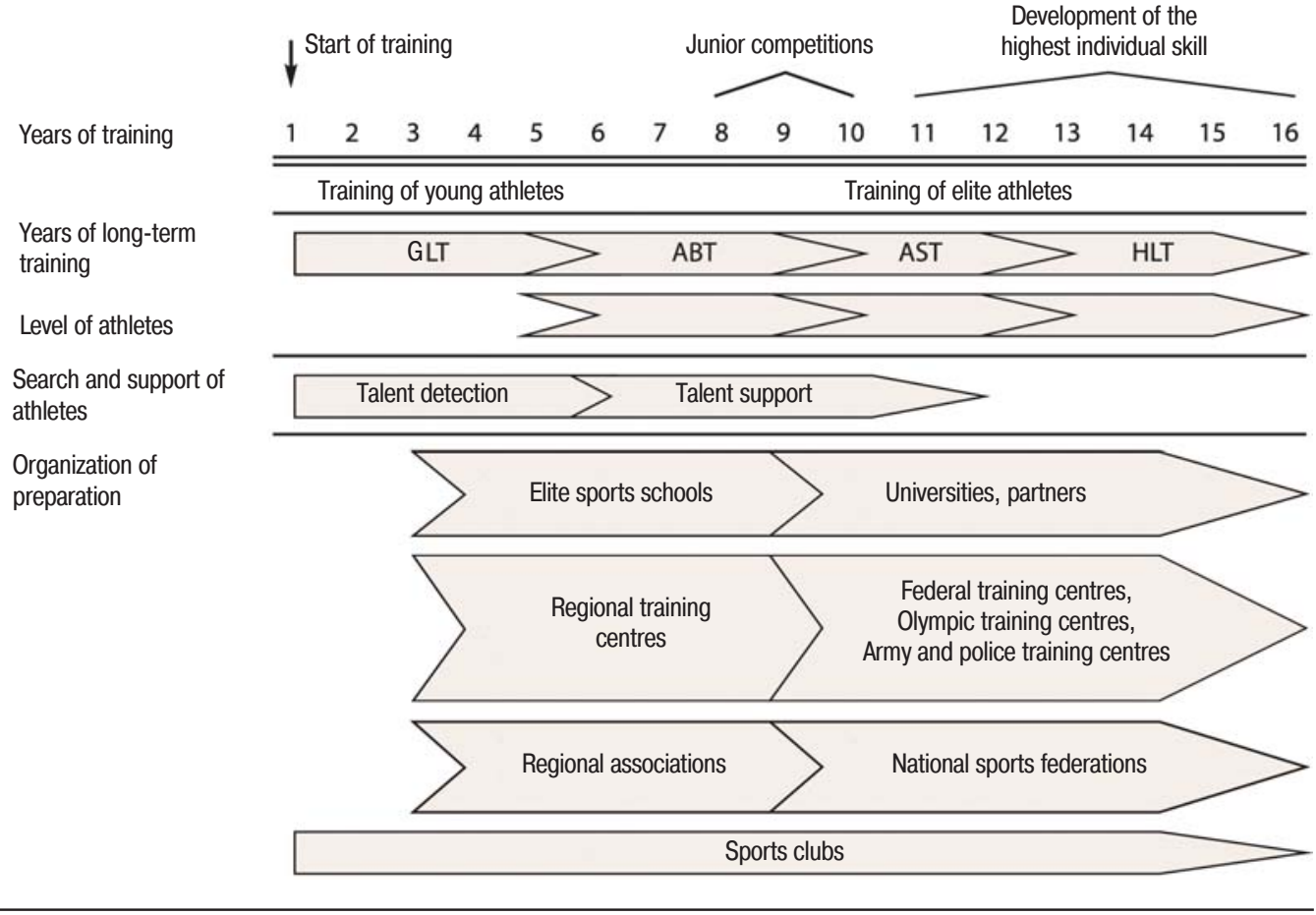




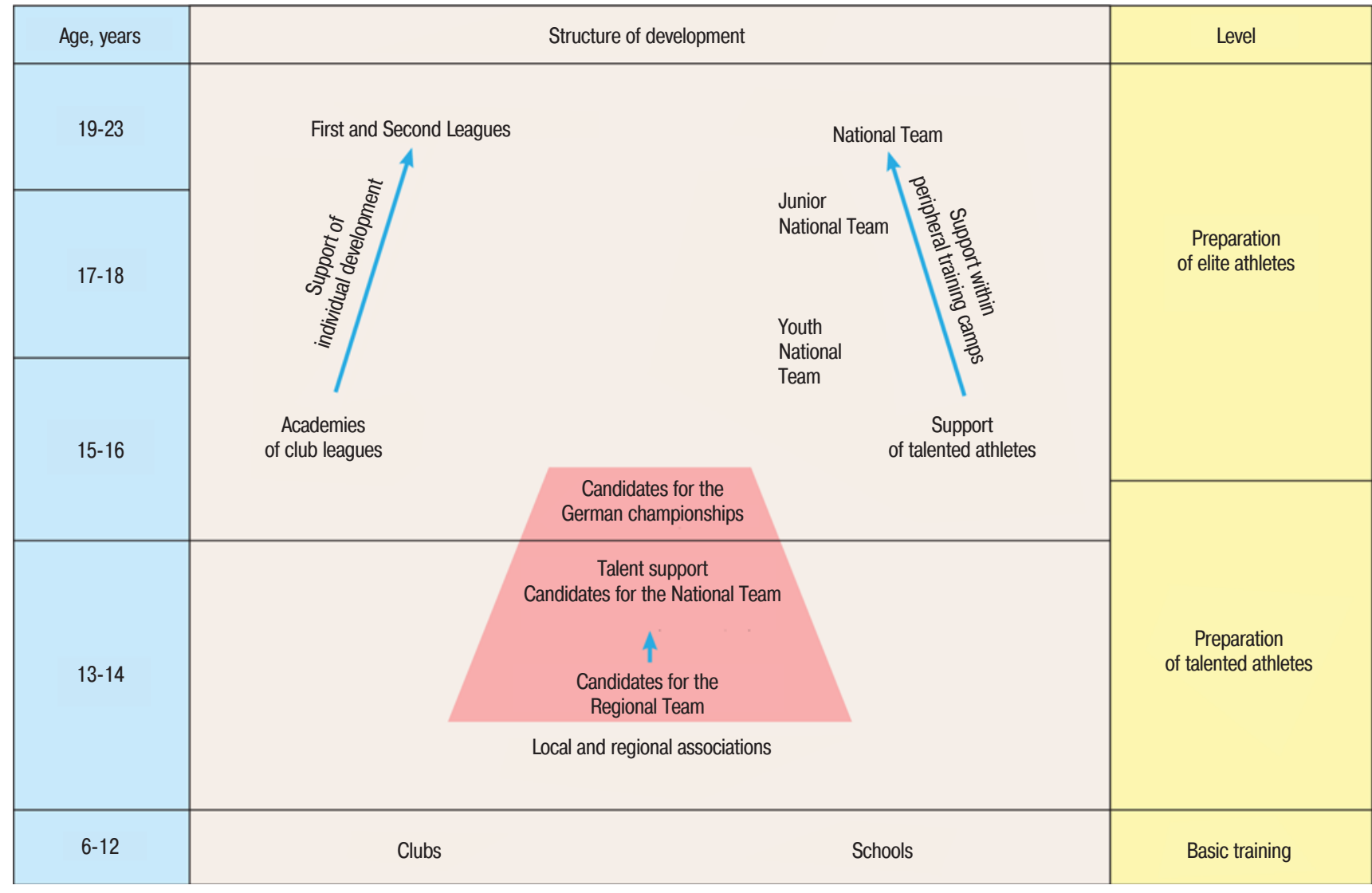

FIGURE 8 - The multistage selection system of promising athletes and their development in the German handball [72]

General scheme of planning

Ways of searching for talents in elite sports

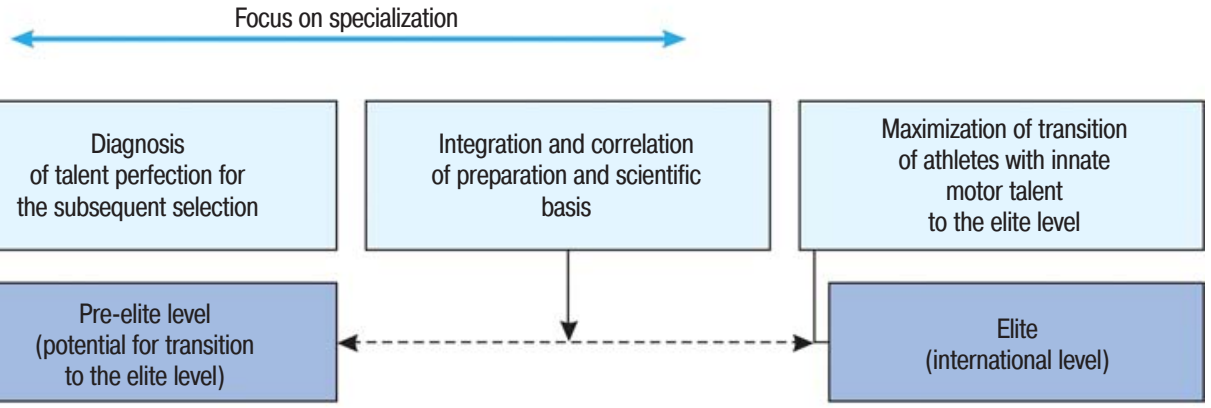

- Specially trained coaches of the pre-elite level must

possess knowledge of working on talent selection

- Create smooth incorporation of talents into the system

of the pre-elite preparation and exit from it

- Make talents reveal themselves and screen them off

when necessary

- Establish connection between the pre-elite and elite

characteristics

- Assess the level of progress

FIGURE 9 - The conceptual model of identification and development of sports talents in Australia [42] 
working with children. Equally important is attempts of the earliest possible identification of children inclined to achievements in sports.

Specialists rightly note that such an approach is unilateral since it does not pay due regard to many external factors inherent to modern sports that impact the dynamics of sports mastery growth and final achievements of athletes $[31,63]$. The range of these factors is constantly growing and their rational use may compensate for certain genetic restraints [8]. Among them are the place of sports in the social life of the society, the attitude to its development and achievements at the state level, the organizational and managerial model of sports development in a country or region, the physical education system at schools, material and technical conditions, traditions, qualification of the coaching staff, the level of scientific and medical support. As the global practice shows, the aggregate impact of these factors allows many athletes who do not seem to have the necessary natural potential to achieve high results. At the same time, no natural potential will be realized without the presence of an appropriate environment. By the way, hence many promising athletes from different countries are striving to train in training centres, where the facilities are set up according to international standards, and coaches are known for their professionalism and results work [1].

\section{CRITERIA USED IN THE SELECTION AND ORIENTATION PROCESSES}

In the process of selection and orientation of athletes within the system of their long-term perfection, it is necessary to orientate at a wide range of indicators that allow to assess:

- the state of health and the level of physical development;

- peculiarities of the body build;

- features of biological maturity;

- properties of the nervous system;

- functional capabilities of the principal systems of an athlete's body and potential for their improvement;

- the level of motor qualities development and potential for their perfection;

- the ability to master sports techniques and tactics, reorganize one's motor skills and technical-tactical schemes;

- the ability to endure training and competitive loads, intensive progress of recovery processes;

- psychophysiological capabilities for muscular-motor and spatiotemporal differentiation;

- motivation, diligence, persistence, determination, and readiness to mobilize;

- the ability to implement different aspects of sportsmanship in extreme conditions typical of significant competitions;

- peculiarities of the previous preparation (the duration and amount of training and competitive activities, reserves for increasing workloads);
- remaining reserves for the improvement of various aspects of preparedness and components of the competitive activities;

- support of parents, families, and their possibilities to create conditions for intense preparation.

The tasks of the specific stage of selection and orientation determine the role and importance of the information obtained by each of the given aspects.

The information about the state of health is equally important for each of the five stages. The characteristics of the body build, the peculiarities of the nervous system, the capabilities and potential for the improvement of the principal functional systems of the body are of utmost importance at the end of the second stage of long-term preparation, when the young athlete's inclination to intense training is detected, the future specialization is determined, and the process of long-term preparation is oriented. The level of the athletic result, the ability to attain the highest results in extreme conditions, the competitive experience, the ability to adapt to the conditions of specific competitions gain a decisive importance at the fourth and fifth stages.

The generalized work experiences of well-known coaches whose trainees have achieved outstanding results point to an exceptionally high level of attention they pay to the task of selecting promising athletes in the process of long-term perfection. Their practices in this respect are extremely diverse and indicate the absence of any standard solutions. Some of them pay considerable attention to the type of body build, the results of testing the functional capabilities of athletes, the identification of latent reserves for the growth of sports mastery; others focus on motivation, diligence, and persistence, assuming that an athlete who ardently wishes to attain outstanding results can achieve them even possessing a rather ordinary physique and capabilities of the principal functional systems; and still others pay special attention to parental support and real opportunities for regular intense training, while giving credits to the study of body build, functional capabilities, and mental peculiarities. However, different priorities do not in any way distract coaches from the need to practice an integrated approach to the problem of selection and orientation of athletes strongly linked to the stages of long-term of preparation. In particular, when working with young athletes, they recommend to focus on the following:

- the adequacy of a body build to the peculiarities of a sport;

- the ability to master techniques;

- coordination abilities - sense of pace, rhythm, developing efforts, time, space, ball, racket, etc.;

- suppleness of movements, ability to relax;

- the ability to quickly recover after training and competitive loads;

- striving for intensive training and achievement of high results;

- competitive eagerness;

- support and responsibility from parents. 
Leading coaches of the world have quite different approaches to the assessment of promising athletes who are at their stages of preparation for the highest achievements and the maximum realization of their individual capabilities. Among the most important qualities that determine the effectiveness of athletes' training, they consider the following:

- a sufficient level of knowledge in the field of sports techniques and training methods, which allows an athlete to actively communicate with a coach, doctor, researchers, and other specialists, analyse the training content, test results, monitor the implementation of the individual plan, recommend amendments to the training process, etc.;

- aspiration for the highest achievements and victories, confidence in one's own strengths and capabilities, high self-esteem;

- the lack of overconfidence, objectivity, ability to critically evaluate one's own actions, draw conclusions from mistakes and failures;

- the ability to endure high training and competitive loads, overcome heavy fatigue;

- commitment for unfailing implementation of the training plan;

- a creative approach to training, selection of the most effective means and methods, ability to individualize common means and methods, find the most effective ones for improving different aspects of preparedness, eliminating flaws;

- the absence of fear of strong competitors, striving to compete with the strongest athletes, ability to demonstrate the best results in main events in the conditions of the acute competition;

- a responsible attitude to one's lifestyle, strict observance of the established regimen subordinated to effective training;

- the advertence to issues of health, serious work on prevention of injuries and diseases;

- a continuous analysis of the diet, the quality of food products and their conformity with the peculiarities of the training process and individual characteristics, the confidence in food additives and pharmacological substances intake preventing doping violations.

Competitive practice as a means of preparing and monitoring its effectiveness plays an important role at all stages of long-term preparation. However, it is of fundamental importance here that the first two stages of longterm preparation generate sports results as a natural consequence of a rationally constructed process of long-term perfection with a total absence of a narrow specialization of athletes and preparation oriented to competitions. Under this approach and taking into account the pace of biological maturation of every athlete, the sports result as well as his/her performance in the training process is a fairly objective criterion for evaluation of his/her prospects. If a coach has not refrained from a premature specialization of an athlete and failed to study the pace of his/her biological maturation, allowed forced elements, then such sports achievements will not reflect objective information.

\section{GENETIC PREDISPOSITION TO ACHIEVEMENTS}

Human motor activity is largely determined by genetics, which is brightly manifested in sports. The crucial role of genes is natural, as each gene predetermines the process of synthesis of a certain protein, enzyme, etc., controls all chemical reactions of a body and identifies its attributes. A unique property of genes is their high stability (invariability) from generation to generation and at the same time there is their ability to mutations - hereditary changes that are the source of genetic variability of an organism. Therefore, it is extremely important to determine the impact of the genetic constitution (genotype) of an athlete's organism (the combination of all his/her genes) on the prospects of his/her sports achievements in during sports selection and orientation. In particular, it is important to determine the inheritance of morphological and functional traits of a human, various characteristics of the motor function, the impact of the genotype on the individual training aptitude, the presence of family concordance in relation to these indicators, etc. [25, 80].

Multiple studies carried out in this field in recent decades testify to the great impact of the genetic constitution on the formation of an athlete's phenotype as a combination of his body properties formed under the influence of heredity and the external environment.

Tables 2 and 3 can explain the general concept of the heritability of morphological and functional traits and motor qualities of an individual. The results of the experimental assessment of heritability and family concordance in a number of the most important indicators of the functional potential of athletes (Table 4) complement this information.

Studies undertaken with the participation of monozygotic and dizygotic twins, parents and children, siblings made it possible in many ways to establish the impact of heritability and family concordance of sports-relevant traits. In spite of significant discrepancies between the results obtained by different researchers, it can be stated that approximately $20-25 \%$ of the possible increase in $\mathrm{VO}_{2}$ max under the influence of rational training is attributed to the athlete's genotype [25, 48, 50, 80]. These data

TABLE 2 - Heritability of the main morphological and functional traits of a human being (according to generalized literary data)

\begin{tabular}{l|l}
\hline \multicolumn{1}{|c|}{ Trait } & Heritability \\
Body, upper and lower limbs length & High \\
\hline Trunk, shoulder and forearm length & High \\
\hline Shoulder and pelvis width & Significant \\
\hline Neck, shoulder, forearm, thigh, shin circumference & Medium \\
\hline Body mass & Significant \\
\hline Ratio of fast-twitch and slow twitch fibres & High \\
\hline Anaerobic capacity & Significant \\
\hline Aerobic capacity & Significant \\
\hline
\end{tabular}


TABLE 3 - Heritability of the main motor qualities of a human being (according to generalized literary data)

\begin{tabular}{l|l}
\multicolumn{1}{c|}{ Trait } & \multicolumn{1}{c}{ Heritability } \\
\hline Time of simple motor reaction & High \\
\hline Time of simple movements & Significant \\
\hline Maximum static strength & Significant \\
\hline Maximum dynamic strength & Medium \\
\hline Speed strength & Significant \\
\hline Coordination & Medium \\
\hline Flexibility & Significant \\
\hline Local muscular endurance & Significant \\
\hline General muscular endurance & High \\
\hline
\end{tabular}

are consistent with the influence of heredity on the indexes of the oxygen pulse, cardiac output, and oxidation potential of skeletal muscles. With regard to the possibilities of the aerobic energy supply system, the differences between the genotypes (between pairs of twins) were 6-9 times larger than the differences within the genotypes (within pairs of twins) [23, 43].

Morphological indexes are most affected by hereditary influence. Hereditary dependence is most clearly manifested in longitudinal dimensions of a body and much less in volumetric. Functional abilities are less inheritable; however, most significant sports indexes (cardiac output, maximal lung ventilation, arterial venous difference, $\dot{\mathrm{V}} \mathrm{O}_{2}$ max level and maximum oxygen debt, etc.) are noted for apparent genetic dependence [14].

The ability to supply oxygen to working muscles is largely attributed to the volume of the left ventricle of the heart and, as a consequence, the systolic volume. Genetic studies have shown that these indexes are largely inherited for both men and women [22]. The frequency of cardiac beat at rest, the ability to transport and utilize oxygen approximately depend on genetic predisposition by $50 \%[56,76]$.

It is shown that the effect of glycolytic and oxidative enzymes is associated with genetic factors by $25-50 \%$. At the same time, no familial concordance was detected in the change in capillary network density, which had increased significantly in all types of muscle fibres as a result of a 20-week endurance training $[61,65]$.

The impact of family concordance on sports achievements is confirmed by numerous cases of successful performance by parents and children, brothers and sisters. Every sport can provide such examples. However, it should be borne in mind that the impact of family concordance is manifested not only in genes but in the lifestyle of a given family (including their attitudes towards sports, competition among family members, etc.).

The genetic contribution to the aptitude for training is very high and may reach up to $75-85 \%$ for certain indexes [14]. This is evidenced by the fact that some athletes respond to one and the same volume of training influences
TABLE 4 - Heritability and family concordance in relation to the indexes of functional preparedness [24]

\begin{tabular}{l|l|l}
\hline \multicolumn{1}{|c|}{ Index } & Heritability & Family concordance \\
$\begin{array}{l}\text { Maximum oxygen } \\
\text { consumption }\end{array}$ & Significant & Significant \\
\hline Heart size & Significant & High \\
\hline $\begin{array}{l}\text { Systolic volume and cardiac } \\
\text { output }\end{array}$ & High & High \\
\hline Composition of muscular tissue & Significant & High \\
\hline Oxidation potential of a muscle & Significant & High \\
\hline Oxidation of lipid substrates & High & High \\
\hline Lipid mobilization & High & High \\
\hline
\end{tabular}

with demonstrated long-term reactions, while the others respond to them insignificantly [64]. For example, an intensive 3-month training aimed at the strength through gained muscle mass may lead to an increase in muscle mass by 8-10 kg, strength - by 50-60\% in some research subjects, the others may show adaptive reactions several times as lower - an increase in muscle mass up to $2 \mathrm{~kg}$, strength up to $10-15 \%$.

The same consistent pattern is manifested in other important indexes, in particular, those expressing the capacity of the aerobic energy supply system. Thus, a 6-month training of a predominantly aerobic orientation of subjects representing a group homogeneous in age and their morphological and functional capabilities delivers different results depending on the individual characteristics of the trainees. The increase in the $\dot{\mathrm{V}}_{2}$ max level does not exceed $2-3 \mathrm{ml} \cdot \mathrm{kg}^{-1} \cdot \mathrm{min}^{-1}$ (4-6\%) for some subjects, while the others have $12-14 \mathrm{ml} \cdot \mathrm{kg}^{-1} \cdot \mathrm{min}^{-1}$ (about $25-30 \%$ ). The increase in the cardiac output also varies extensively from $0.5-1 \mathrm{~L} \cdot \mathrm{min}^{-1}$ to $5 \mathrm{~L} \cdot \mathrm{min}^{-1}$.

A very high or very low predisposition to trainability is inherent to a small number of athletes - about 3-5\%. It should be noted that a specific predisposition to training of certain motor qualities and functional capabilities is largely attributed to the athlete's somatotype, his/her morphological and mental characteristics. High trainability in relation to some indexes may be accompanied by a lower or higher on in relation to others. For example, a high trainability of muscle mass and maximum strength is usually accompanied by a poor predisposition to the development of endurance in aerobic exercise. Predisposition to the development of coordination abilities is usually accompanied by a significant adaptive resource in flexibility, the time of simple and complex reactions, speed qualities.

High trainability does not a guarantee the achievement of high sports results. Athletes with high response to training impacts, which manifests itself in an intensive course of adaptation processes, often exhaust their adaptive resource very quickly, and the increase of their capabilities slows down and stops further on. Eventually, these 
athletes often yield to those who show slower pace but longer duration of the process of adaptive changes under the impact of task-oriented training. For example, $90 \%$ of the genetically determined adaptation resource of the aerobic energy supply system capacity, expressed in relative indexes of $\dot{\mathrm{V}} \mathrm{O}$, max, is realized by some athletes after 10-12 months of intense training, while others need at least 2-3 years for this. At the same time, studies of monozygotic twins involved in long-term (20 weeks) aerobic training programs showed a high degree of concordance in the adaptation effect within each monozygotic pair [24].

The nature of genetic impact on trainability remains mostly unexplored. However, it may be stated with certainty that the intensity of adaptation reactions, especially to power, speed, aerobic, and anaerobic training, is largely determined by genetic factors.

For more than two decades, specialists studying natural predisposition to achievements in different sports focused their close attention on sprinters from the countries located in the western part of Central Africa (Ghana, Cameroon, Côte d'Ivoire, Namibia, Nigeria, and Senegal) as well as from Jamaica. Just as much interest was given to performances of long-distance runners and marathoners from the countries of eastern and northern Africa, especially Kenya and Ethiopia, which have remained unbeaten for many years in the world sports arena. Black sprinters from the western region of Africa possess an expressed mesomorphic type of body build, a relatively short trunk and long legs, powerful muscle mass, high percentage of fast-twitch fibres, low percentage of fatty tissue, large capacity of the alactic energy system, highly positioned centre of gravity. They have $8 \%$ less slow-twitch fibres and the same number of fast-twitch fibres compared to representatives of the white race. Additionally, representatives of countries in western Africa were found to have a $30-40 \%$ increase in the enzymatic activity (creatine kinase, phosphofructokinase), which ensures power and capacity of anaerobic processes $[19,58]$. These data testify that people from West African countries have a pronounced predisposition to sprint work.

Experts state that most today's outstanding sprinters with dark skin, competing for different countries, almost certainly have ancestors from countries in the western part of Central Africa. For example, Jamaica - an island country with a small population (about 2.9 million people) - has delivered many outstanding sprinters to the world in recent years. According to a very popular hypothesis, the outstanding success of Jamaican runners is largely due to the fact that they are descendants of West African black slaves brought two or three centuries ago to the countries of the New World in the course of the transatlantic slave trade. They brought in the healthiest and strongest slaves. Conditions of their multiweek transportation across the Atlantic were deplorable, and a significant part of slaves died throughout the journey. The strongest ones having special natural abilities survived [53].

Black long-distance runners and marathoners from the northern and eastern regions of Africa typically possess the ectomorphic body build, a large volume of slow-twitch fibres, sufficiently high oxidizing ability of fast-twitch fibres, long, lightweight lower limbs, extremely low percentage of fat tissue, exceptionally high aerobic capacity and their performance economy. Black runners from these regions differ from those of the white race in higher $\dot{\mathrm{V}} \mathrm{O}_{2}$ max values, which often exceed $80 \mathrm{ml} \cdot \mathrm{kg}^{-1} \cdot \mathrm{min}^{-1}[44,68]$. High $\dot{\mathrm{V}} \mathrm{O}_{2}$ max values are combined with high performance economy - the ability to run at a certain speed with low energy consumption or to develop a higher speed with the same energy consumption level. It was shown that black athletes use a greater part of $\dot{\mathrm{VO}}_{2} \max (92-94 \%)$ with the same level of lactate in blood than their fellow countrymen - representatives of the white race (86-88\%) [78, 81].

Therefore, there are pronounced differences in the type of body build, the structure of muscle tissue, the potential of various energy supply systems, motor abilities, etc. between the ethnic groups inhabiting the western part of Central Africa and northern Africa, and the dark skin colour is only an outer trait that disguises significant differences. According to experts, a prerequisite for such a situation is the lack of genetic exchange between the mentioned African ethnic groups due to geographic, historical, and social reasons, which ensured the differentiation of their development [36].

These differences can be strikingly confirmed by the names of outstanding athletes - representatives of different regions of Africa. Only after 2000, a large group of athletes emerged on the world arena and achieved remarkable results in long distances - S. Sihine, G. Gebremariam, S. Kipketer, A. Mezgebu, R. Limo, P. Ivuti, P. Makau, S. Wanjiru, K. Bekele, B. Karoki, A. Kirui, W. Kipsang, and others. All of them are representatives of the countries of Northern and Eastern Africa. The list of outstanding sprinters - representatives of ethnic groups inhabiting the territories in the countries south to the Sahara, in western Africa M. Greene, B. Surin, A. Boldon, O. Thompson, D. Chambers, F. Fredericks, and others.

Many specialists who have thoroughly studied the phenomenon of outstanding success of runners from different regions of Africa and Jamaica do not tend to overestimate the role of genetic traits $[58,74]$. Not denying the impacts of individual genetic profiles on the predisposition to achievements in different running disciplines, experts believe that the living environment, traditions, lifestyle, the training systems, high popularity and mass character of such competitions have no less importance [55, 73].

A natural predisposition of Jamaicans to high achievements in track and field sprint would not have led to the formation of a large group of outstanding athletes if the country had not created a full-fledged and effective training environment. In Jamaica, an effective model of identification and training of promising athletes has existed for many years and is constantly being perfected. The system aims at creation of intense competition and realization of natural potential of each gifted athlete in the process of long-term perfection [67]. 
Studies have shown that the majority (81\%) of highperforming long distance runners from Kenya come from the Great Rift Valley region - home to about $25 \%$ of the Kenyan population. The same situation is observed with the strongest runners of Ethiopia: $38 \%$ of them live in the Arsi Zone, the population of which makes up only $5 \%$ of the country's population. Both territories are situated on uplands; they are distinguished in a specific lifestyle of children and youth, when running is an element of culture and vital necessity. Organized identification and development of talents are almost absent here, and the constant emergence of top-class runners is a natural result of the confluence of many factors - genetic predisposition, living environment, and lifestyle [58, 68, 73].

Rural dwellers have to make daily jogs to school at distances from 5 to $10 \mathrm{~km}$, which makes up $100 \mathrm{~km}$ on average per week. At schools of Kenya and Ethiopia, running - the simplest of motor activities - is given great importance. Many children run along with exercising famous runners of their village, trying to imitate their technique, to compete on short stretches. Studies show [68] that young athletes inhabiting rural areas have a 30\% higher level of $\mathrm{V}_{2}$ max than their urban peers. As a result, rural dwellers who devote themselves to running practice are able to perform a larger amount of work with an intensity corresponding to oxygen consumption of more than $80 \%$.

An equally important component of success of Kenyan and Ethiopian runners is training in large groups. Constantly competing and bringing themselves to the state of deep fatigue, athletes get used to overcoming painful sensations, developing mental resistance to the most severe forms of fatigue emerging in the end of the race. High-intensity training works for the adaptation of fast-twitch muscle fibres (type $2 \mathrm{a}$ and $2 \mathrm{~b}$ ), increasing their ability to produce ATP through an aerobic mechanism, simultaneously stimulating the mobilization of the glycolytic mechanism in all types of muscle fibres. This is clearly demonstrated by running events at the World Championships and Olympics Games: in the final stages, black athletes from these countries have an overwhelming advantage over their opponents.

Acknowledging the great impact of genetic predisposition on achievements in modern sports, it should be noted that the scope of knowledge in this field is largely based on assumptions and not on exact proven facts. In particular, it is still not known, which genes determine the level of achievements in activities associated with speed qualities or endurance, and the results of associative studies provide only relative insights into the factual role of different candidate-genes [36, 52]. The situation seems even more complicated in view of the fact that physical abilities are most likely determined by a complex combined impact of the whole group of genes [62]. Many laboratories across the world undertake research of genes, which allow to assess the potential abilities of children to achieve high results in a particular sport. However, presently, there is not much success in finding such marker genes, since linkage of these markers with the biological consequences that result from training has not been established. Naturally, it makes to identify the prospects for the development of certain qualities based on the genetic profile and to arrange appropriate training. However, at the present stage of knowledge in this field, one may say that it is possible in principle but far from reality [21].

\section{PECULIARITIES OF BODY BUILD (CONSTITUTION) OF ATHLETES}

The athlete's body build can provide him with mechanical, biomechanical, and physiological advantages in training and competitive activities. Therefore, as early as at the primary and preliminary stages of selection, it becomes necessary to classify the body structure of young athletes according to a certain constitutional type. Although the human constitution undergoes certain changes in every age period; on the whole, it is more or less constant and is largely determined by hereditary factors.

It should be noted that there is no single approach to the definition of a human constitution. This applies both to the definition of the very concept of "the constitution of a human being" as well as to the diagnosis and classification of constitutional types. The most common approaches to determining the human constitution on the basis of morphological criteria are the degree of muscular and fat deposit development, body height and weight, features of the skeleton, etc. Under this approach, most specialists tend to use the term "somatotype" to characterize the body constitution.

Let us review one of the most popular schemes among many schemes used to define a human constitution, according to which three somatotypes are determined.

Pyknic endomorphic type features a protuberant thorax, soft rounded forms, relatively short limbs, short wide hands and feet, large amount of subcutaneous fat.

Athletic mesomorphic type features a trapezoid shape of the trunk, contracted pelvis, strong shoulder girdle, welldeveloped muscular system, massive bones.

Asthenic ectomorphic type features a flat long thorax, relatively wide pelvis, thin body and weakly developed subcutaneous base, long thin limbs, narrow feet and hands, minimum amount of subcutaneous fat.

Naturally, the constitutional capabilities of most individuals cannot be narrowed down to these extreme three types. Such a division provides only a general idea of the fluctuation ranges in the human constitution; that is why, the practice of sports selection is more oriented to three continuously distributed components of the body build, which are as follows: endomorphic, mesomorphic, and ectomorphic. Endomorphism is characterized by roundness and softness, increased amount of fatty tissue, predominance of the abdomen above the thorax, high shoulders, short neck, smooth contours of the body, and lack of muscle relief. Mesomorphism features a straight trunk, tight, relief and outstanding muscles, massive bones, thick 
forearms, wrists, hands and fingers, big thorax, broad shoulders, relatively narrow waist, and rough skin. Ectomorphism manifests itself in fragility and subtlety of the body, leanness, thin bones and muscles, drooping narrow shoulders, relatively long limbs and short trunk, absence of muscle relief.

The most popular method of somatotype definition uses photographs of a person taken in three projections. Based on the analysis of these photographs, the degree of each component expression is determined, and the results are recorded into special diagrams. The expression of each of the three components is assessed by the 7-point system: the highest score (7) corresponds to the maximum expression of the component, and the lowest (1) - to the minimum. In this way, somatotype 7-1-1 speaks of the maximum endomorphism, 1-7-1 - maximum mesomorphism, 1-1-7 - maximum ectomorphism. The extreme variants are rare, the most common are mixed somatotypes such as 3-5-1, 4-3-3, 3-4-4, 3-6-2. It should be mentioned that all three components are interdependent: an increase in one leads to a decrease in the others, which is why high values of one component essentially eliminate high values of the other two components. When assessing a somatotype, the sum of all three scores should not exceed 12 and cannot be lower than $9[12,75]$.

The somatotype classification process is carried out through studying of specifically positioned photographs and comparing them with pictures of standard somatotypes. When a group of athletes is examined, it is advisable to record the results of the research into a special diagram.

Many years ago, D. M. Tanner carried out classical studies of somatotypes of Olympic athletes in comparison with ordinary people and students of specialized educational institutions [75]. Students not practicing sports (Figure $10 a$ ) tend to have intermediate types with a relatively moderate content of endomorphic, mesomorphic, and ectomorphic components. For the majority of students of sports colleges (Figure $10 b)$, a mesomorphic type of body build
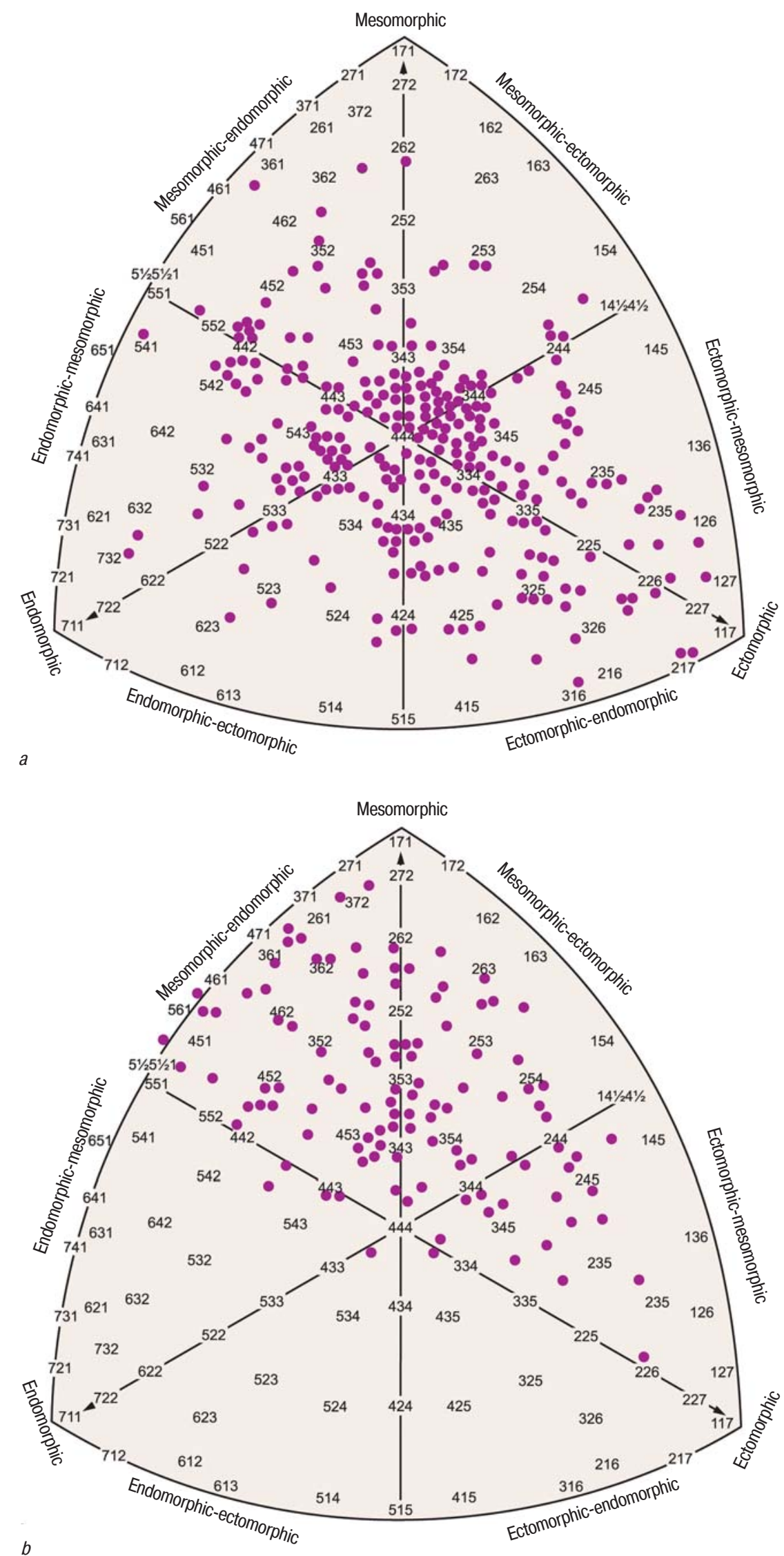

FIGURE 10 - Distribution by somatotypes:

$a$ - university students $(n=283) ; b$ - students of a sports college $(n=114)[75]$ 


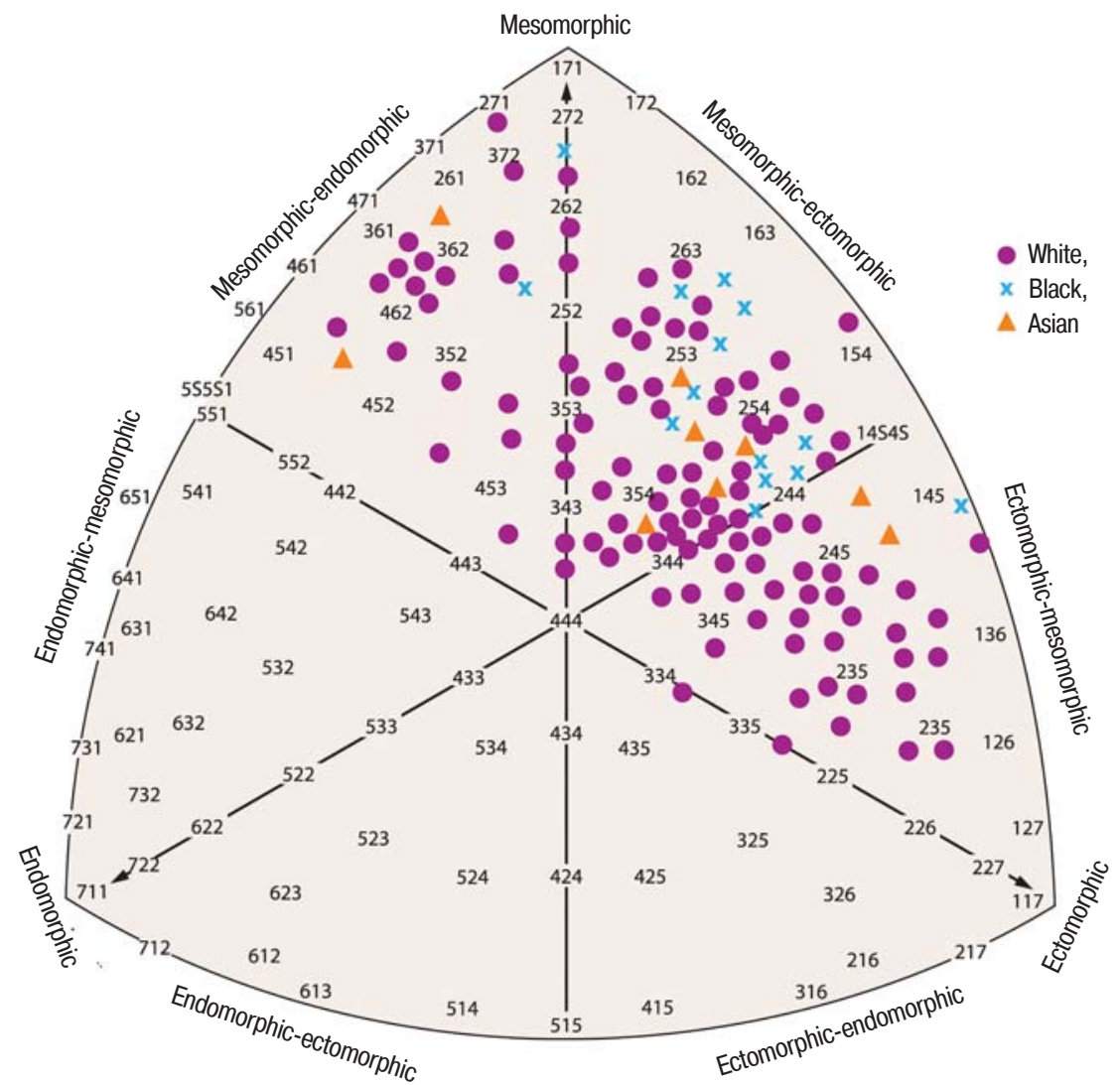

FIGURE 11 - Distribution by somatotypes of track and field athletes-participants of the Olympic Games ( $n=137$ ) the studies of large groups of male and female athletes specializing in different sports [38] showed that athletes possess more pronounced mesomorphic and ectomorphic components in comparison with people not doing sports, that is, they have a greater muscular mass and a lower percentage of fatty tissue. Long-distance runners, swimmers, basketball players may be categorized as a mixed mesoectomorphic type as these components are quite well pronounced (Figure 12). Female long-distance runners possess a mesoectomorphic somatotype, and female swimmers and throwers are endomesomorphic.

Specialization in this or that type of competitions essentially influences the requirements set forth to somatotypes of athletes. For instance, in swimming, pure sprinters (distances of 50 and $100 \mathrm{~m}$ ) possess a distinctly expressed mesomorphic type. The increase in the distance length (100 and $200 \mathrm{~m}$ ) correlates with a decrease in the mesomorphic rating and an increase in the ectomorphic one (Figure 13). is typical. Olympic athletes are characterized by a complete absence of a pronounced endomorphic type (Figure 11). Track and field athletes of various specializations vary considerably in their body types. In comparison with sprinters, long-distance runners feature a decreased frequency of the mesomorphic type and an increase in the ectomorphic type. Throwers have a high level of the mesomorphic type and a low level of the ectomorphic one. The same is typical for weightlifters. In comparison with weightlifters and throwers, wrestlers have a tendency to a slight decrease in the mesomorphic type rate and an increase in the ectomorphic type.

Other studies carried out in this field $[15,32,39,40,46,77$, 78, 84] provided only a slight development and elaboration of various provisions made by D. M. Tanner [75]. For example,

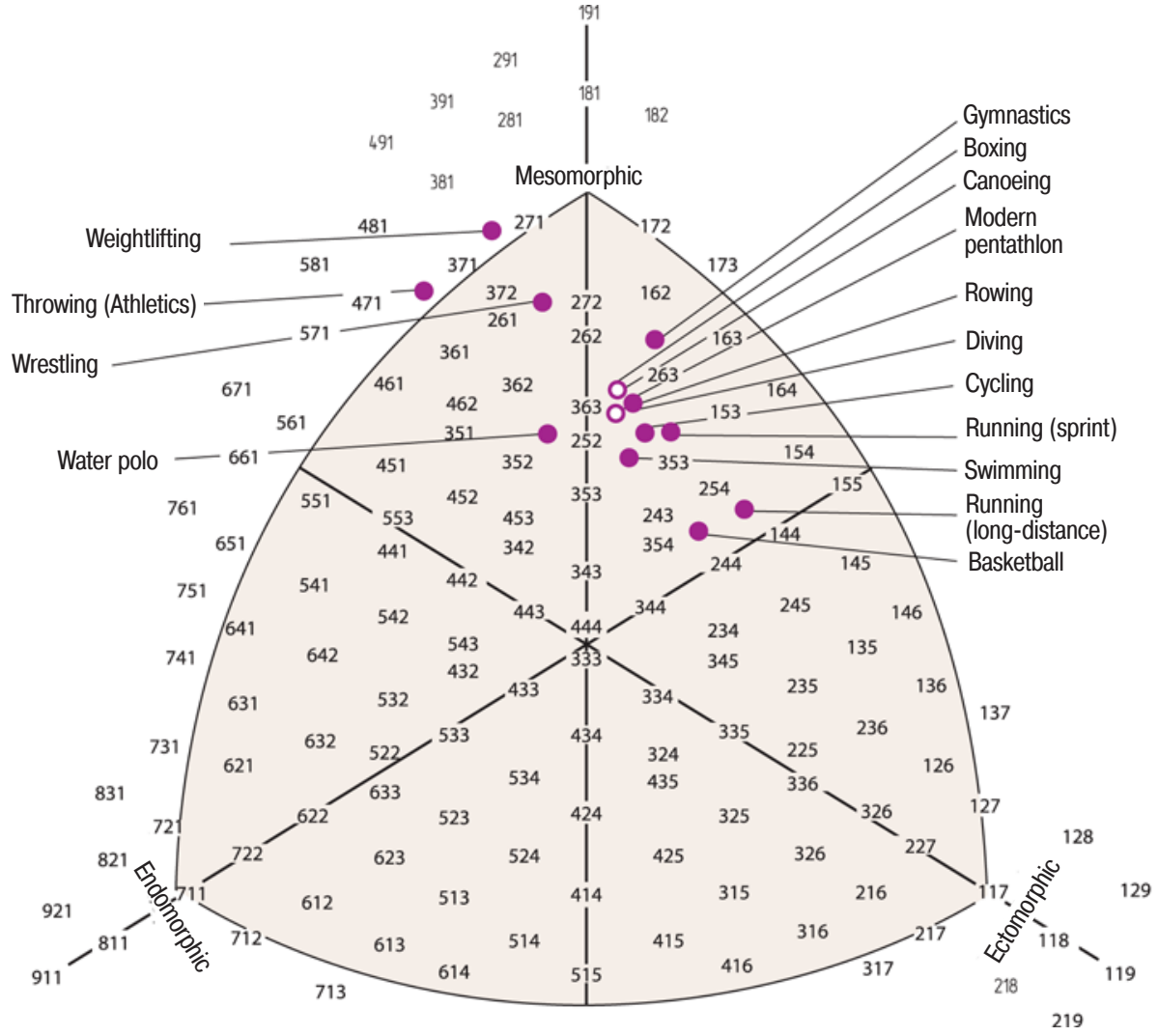

FIGURE 12 - Somatotypes of athletes specializing in different sports 
Many specialists link somatotypes to physical qualities, physiologic and biochemical processes, and mental personality traits [77, 78]. It is believed that the highest level of oxidative processes is observed in individuals of the asthenic and athletic constitutional types. A relation between endomorphism and such markers of temperament as balance, sociability, and mild manner has been discovered. Mesomorphism is found to have a correlation with such traits as risk taking, decisive actions, and aggressiveness, whereas ectomorphism is associated with emotional restraint, reticence, unsociability, tolerance to external factors [20]. These dependencies are of a statistical nature and are not fully reliable if applied to a single person, but they may be extremely helpful in developing an overall strategy for selection and orientation of athletes of different constitutional types [40].

However, it should be noted that data on the body build optimal for this or that sport are not stable and can vary significantly for a number of reasons. Among them is the constant growth of sports achievements and competition on the world sports arena, which increases the requirements towards a body build and distances the body structure of outstanding athletes farther from that of average people. Of great importance is the process of globalization, which has led to an intensive involvement of representatives of various ethnic groups, previously poorly represented in the Olympic sports. Trends in the technique development of certain sports, amended assessment criteria for evaluation of performance in competitive activities often change significantly (sometimes radically, as in women's gymnastics) the requirements for the optimal body build of athletes capable of achieving outstanding results. A variety of requirements for the body structure of athletes are set by sports, in which competitions are held in different weight classes (boxing, wrestling, weightlifting, etc.). Achievements in the field of training techniques may significantly affect the requirements towards the body build of athletes [10]. For example, achievements in swimming techniques and techniques of energy supply systems increase unexpectedly led to an increase in the body length and weight of sprinter swimmers.

A significant change in the requirements for the body build of athletes dictated by the development of different sports is manifested in the dynamics of such clearly evident indexes as the body length and weight of the strongest athletes. For example, the height of the majority (about $90 \%$ ) of outstanding sprinter swimmers specializing in freestyle and butterfly stroke swimming in the 1960s and 1970s ranged from 175 to $185 \mathrm{~cm}$ with a body weight from 75 to $80 \mathrm{~kg}$. In modern swimming, the leaders are the swimmers, whose height is $190-200 \mathrm{~cm}$ and body weight is $86-100 \mathrm{~kg}$. In women's gymnastics, there changes were opposite: the strongest athletes of the 1960s and 1970s had an average height of $160 \mathrm{~cm}$ and a body weight of $50 \mathrm{~kg}$, the current top performers possess a height of $140-150 \mathrm{~cm}$ and a body weight about $35-45 \mathrm{~kg}$.

\section{PREDISPOSITION OF ATHLETES TO WORK IN A DIFFERENT DIRECTION}

Objective selection of promising athletes, their orientation to this or that type of competitions and, especially, at the formation of an individual model of preparedness and competitive activities are complicated until the end of the puberty period of children. This is conditioned by the exceptional speed and individual peculiarities of the development processes of the central nervous system, musculoskeletal system, psychomotor capabilities, and energy supply systems. By the end of the puberty period, a predisposition to work with a specific orientation becomes quite clearly visible; its identification makes it possible to orient a young athlete at a specialization in specific types 


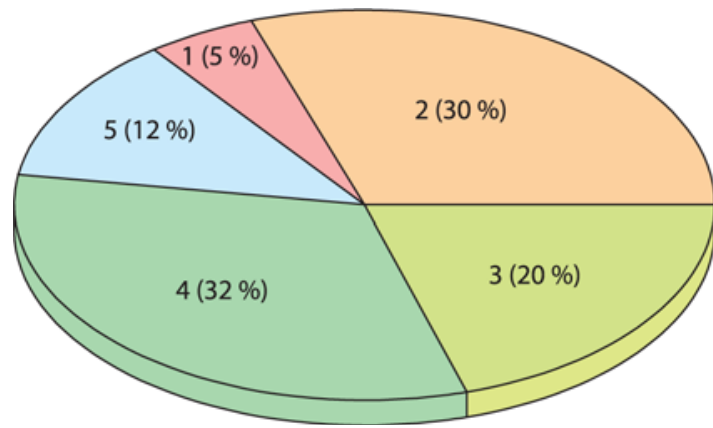

FIGURE 14 - The general representation of young athletes (13-14 years old) within different groups:

1 - sprinters; 2 - mixed type with a predisposition to sprinting work; 3 - mixed type with mixed abilities; 4 - mixed type with a predisposition to long-distance work; 5 - long-distance performers [2]

of competitions and also to construct his training process rationally, relying on natural inclinations.

Mass examinations of young athletes at the second stage of long-term preparation, with the use of a wide range of different indexes, allowed to divide trainees into several groups depending on their inclination to sprint or long-distance work.

The first group consists of athletes of pronounced sprinter abilities (sprinters).

The second group comprises athletes of mixed abilities with dominating predisposition to sprinting activities (mixed types with a predisposition to sprinting work).

The third group includes athletes of mixed abilities with a relatively balanced level of their development.

The fourth group includes athletes of mixed abilities, with dominating predisposition to long-distance activities (mixed types with a predisposition to long-distance work).

The fifth group consists of athletes with pronounced long-distance capabilities (stayer).

In general, the distribution between these groups is uneven. The pure sprinting or long-distance types are relatively rare, most athletes fall into different intermediate types (Figure 14).

Athletes of each of the five groups differ significantly in their main anthropometric traits, capabilities of energy supply systems, psychophysiological characteristics, the level of development of their special motor qualities.

As a rule, athletes of the first group belong to the mesomorphic type of the body build; they are distinguished by high body height and weight indexes, circumference measurements, and the length of the upper and lower limbs. They possess high rates of capacity and volume of the lactic and alactic systems of energy supply, mobility, a large number of Type2a and Type2b fibres, a high level of maximum and high-speed strength, and the capacity of working movements of hands and feet. Indexes of psychophysiological characteristics of these athletes testify to a high lability and reactivity of their nervous system, and special motor tests demonstrate a significant level of high-speed, speed-strength, and power capabilities. Simultaneously, athletes of this group have low relative in- dexes of the aerobic energy supply system, low economy of performance.

Athletes belonging to the third group are characterized by a sufficiently high capacity and volume of the anaerobic lactate energy supply system, high mobility and capacity of the aerobic energy supply system, resistance to heavy fatigue caused by the accumulation of lactic acid in the muscular tissue. Simultaneously, they are significantly inferior to the athletes of the first group by the level of speedpower capabilities, reactivity of the nervous system, but significantly exceed them in the economy of performance, capacity and volume of the aerobic energy supply system.

Athletes of the fifth group are distinguished by clearly pronounced markers of the ectomorphic body type, an exceptionally high level of capacity and volume of the aerobic energy supply system, and high economy of performance. During special tests, these athletes demonstrate a fairly high level of endurance in the aerobic work. At the same time, they have low rates of speed, speed-power, and power capabilities, a slow response to various stimuli, low lability and reactivity of the nervous system if compared with athletes of the first and even the third groups.

The constitution of athletes belonging to the second group, the capabilities of their energy supply systems, the level of development of their motor qualities, neuropsychic traits take an intermediate position between those of athletes belonging to the first and third groups. As for athletes belonging to the fourth group, they occupy an intermediate position between the athletes of the third and fifth groups by the same indexes.

The attribution of young athletes to a certain group can be objectively carried out by the end of the puberty period of their lifespan development. However, the attribution of athletes to these groups at an earlier age significantly reduces the objectivity of such assessment [10].

\section{PRIMARY SELECTION AND ORIENTATION AT THE FIRST STAGE OF THE LONG-TERM PREPARATION}

The methodology of sports selection at the initial stage of preparation is determined by the main task of the first stage of selection - to help a child choose a proper sport for sports perfection. An adequate solution of this task not only speaks of the effective work of children and youth sports schools, individual coaches, but also possesses a profound social meaning. Successful sports activities allow a young person to reveal his/her natural talents, clearly feel the results of invested efforts and self-confidence are a way of self-fulfilment. All this lays good foundations for his/ her future life and active position in any field of activities.

One of the key points that determine a child's future sports progress is the age of his/her first sports involvement (Table 5). At this age, the majority of the strongest athletes got engaged into sports activities. In some cases, one should not deny admission of children whose age is slightly higher than the given limits to sports clubs. 
TABLE 5 - The best age to start training in different sports

\begin{tabular}{l|c|c}
\multicolumn{2}{c|}{ Sport } & \multicolumn{2}{c}{ Age, years } \\
\hline Swiscipline) & Boys & Girls \\
\hline Canming & $8-11$ & $7-10$ \\
\hline Rowing & $12-14$ & $12-14$ \\
\hline Cycling & $13-15$ & - \\
\hline Speed skating & $12-14$ & $12-14$ \\
\hline \multicolumn{1}{|c|}{$100-400 \mathrm{~m}$} & $13-15$ & $13-15$ \\
\hline \multicolumn{1}{|c|}{$800-1500 \mathrm{~m}$} & $12-14$ & $12-14$ \\
\hline Gymnastics & $13-15$ & $13-15$ \\
\hline \multicolumn{1}{|c|}{ artistic } & & \\
\hline \multicolumn{1}{|c|}{ rhythmic } & $5-7$ & $4-7$ \\
\hline Figure skating & - & $5-7$ \\
\hline Weightlifting & $7-9$ & $6-8$ \\
\hline Wrestling & $13-15$ & $12-14$ \\
\hline Handball & $12-14$ & $12-14$ \\
\hline Volleyball & $12-14$ & $11-13$ \\
\hline Football & $12-14$ & $11-13$ \\
\hline
\end{tabular}

It should be kept in mind that the search for gifted children requires a multidisciplinary approach based on anthropometric, physiological, neuroregulatory potential and capabilities, sociological, psychological, and cognitive background [79]. Most of these inclinations cannot be detected until a certain level of development of various functional systems of the body and without the analysis of children's learning and training processes. That is why, experts aptly note that a fairly accurate determination of promising children and adolescents as well as their orientation to specialization in a particular sport can be completed after the puberty period and 4-5 years of primary and preliminary basic training. This suggests that attention should be focused on the quality of the training process and not on the attempts to solve the problem of selection and orientation in childhood [63]. An early assessment of athletes' predisposition to higher achievements is fraught with serious mistakes, exclusion of promising children with great potential [37]. Anxiety for early identification of sports talents should be avoided as well as any early specialization $[18,57,63]$. This has no prospects because of:

- the inability to link genetic preconditions with the influence of environmental factors;

- the lack of a close relationship between crosssectional studies of genetic preconditions in childhood and further development, which is non-linear with regard to the most important components of preparedness;

- a variety of models of preparedness and competitive activities conditioned by compensatory capabilities of athletes' bodies, the ability to achieve high results at rather ordinary levels of development of a number of significant anthropometric or physiological characteristics;
- largely unpredictable changes in bodies of young athletes, which may take place during puberty;

- an insufficient development of the nervous system and difficulty to predict a number of mental qualities that are of vital importance for achievements in sports.

A precondition for the primary selection of children is to organize it after the course of compulsory education of children in the basics of sports. It is advisable that such a course contains at least 30 lessons. This will ensure not only the acquisition of useful life skills by children, but will also significantly improve the assessment of their prospects. In the absence of mass education, it is easy to mistake those better at swimming, running, or performing gymnastic exercises for the more capable ones.

At the initial assessment of promising children, one should found upon qualities and abilities that determine success in elite sports. Temporary attributes that manifest themselves only at training cannot be used as selection criteria. For example, defining abilities, one cannot take into account only the speed of mastering sports techniques. The experience shows that children of small stature and strong build master sports equipment better and progress faster at the initial stages of training. However, it is them who drop out as not very promising ones at the first stages of long-term preparation. At the same time, lean and tall children, having difficulties in mastering techniques at the early stages, become top-class athletes later on.

It is necessary to start assessment of a child's perspective with measuring total body dimensions in conjunction with visual assessment of his/her appearance. For instance, children of high stature should be given preference in case of swimming and rowing. In rowing, adolescents with a long trunk, large arm span and broad shoulders should be in the focus of attention. Proportionally built children with smooth muscular system (with indistinctly marked relief), light skeletal frame, thin ankles and wrists, large feet and hands are selected for swimming. Selecting bicyclists and skaters, one should give preference to adolescents with a small body mass index and well-developed thigh and lower leg muscles. Experienced coaches pay attention at these indexes in their initial assessment of children predisposed to sports training.

In such sports where functional capacities of the aerobic energy supply system (cross-country skiing, long-distance running, cycling) play a critical role, it is necessary to assess such indexes as $\mathrm{VO}_{2}$ max and pulmonary vital capacity (PVC) already at the primary selection. Twelveyear-old adolescents who wish to go in for cross-country skiing should have the level of $\mathrm{VO}_{2} \max \left(\mathrm{L} \cdot \mathrm{min}^{-1}\right)$ of at least 2-2.5, a relative value of $\mathrm{VO}_{2} \max \left(\mathrm{ml} \cdot \mathrm{kg}^{-1} \cdot \mathrm{min}^{-1}\right)$ of at least 47-50, the PVC index not less than $3000-3500 \mathrm{~cm}^{3}$. In combination with morphological data, these indexes will shape understanding of the future prospects of a child.

In the primary selection process, basic pedagogical tests should be widely used to assess the level of motor abilities of children. And preference should be given to 
those tests that evaluate motor abilities based on natural potential. In particular, special attention should be paid to tests that allow assessing speed, coordination, and flexibility. For instance, the level of coordination abilities may be determined by the quality of complex exercises performed in the process of their learning.

Body size, muscular volume and capacity of boys and girls before they enter puberty practically do not differ. Therefore, in childhood, the differences between boys and girls in the level of their speed-strength qualities, endurance, and other motor qualities are minimal. This results in the identical competitive performance and in some cases the advantage of girls over boys [38]. Therefore, relatively low achievements of boys in various tests and, especially, in competitive activities should not be perceived as negative in terms of their perspective.

Of great importance at children's selection is the assessment of their state of health. The absence of disorders in the normal functioning of the body is one of the most important conditions for achieving success in modern sports. Even minor deviations in the state of health may significantly impair the adaptive capacity of a body.

An important point at the examination of children during their selection for sports is a comparison of their passport and biological age. It is well known that the progress of puberty induces differences in the development of children of the same passport age. The experience of children's and youth sports schools testifies that children with accelerated biological development are often selected, but they quickly lose their advantages and quit sports early enough in the future. Whereas, as a rule, children with a normal course of development or having signs of delayed biological development achieve significantly greater success in the subsequent stages of sports perfection. At the age of 16-17, such children experience a sharp increase in the functional capacity of various organs and systems of the body, while early developers observe stabilization or even a decrease in their morphological and functional capabilities.

According to different authors, up to $15-20 \%$ of 11-13-year-old children are characterized by accelerated rates of puberty. They surpass their peers in height and body weight, muscle mass, the level of development of motor qualities (especially strength), the ability to master sports techniques, etc. And although these differences seem to be slight in comparison to normally developing children - just 2-4\% and to retardants - 4-8\% [83], but they are sufficient to ensure that early developers have a noticeable advantage in the amount and intensity of training activities as well as the level of their athletic performance.

At early stages of selection, it is essential to consider mental indicators of predisposition to sports activities. At the primary selection, the main indicators are the desire of a beginner to do sports, eagerness to obtain high marks when performing tasks, determination and assertiveness in game situations, courage at performance of new tasks.
In the process of comprehensive assessment of children's prospects for achievements in sports, rather unexpected criteria are often discovered. For example, dates of birth of athletes are of great importance for a successful career in sports games. Children born in the first 2-3 months of the year have an obvious advantage in age group competitions as compared with children born in the second half of the year [34]. They make up the majority in teenage and youth game teams and, of course, they have undisputed advantages over players born at the end of the year [27]. For example, the entire history of the National Hockey League shows that the largest number of players was born in January and February, and the smallest - in November and December [35]. In Brazilian or German football, the situation is different: the beginning of the championships in August gives an advantage to young players born in summer [54]. On the contrary in women's gymnastics, the modern tendencies of which are focused on early specialization, children who were born in the last months of the year have the advantage.

\section{PRELIMINARY SELECTION AND ORIENTATION AT THE SECOND STAGE OF LONG-TERM PREPARATION}

At this stage of selection, the main criterion for assessing the perspective of a young athlete is his/her ability to effectively athletic perfection. After 2-3 years of initial training and long before reaching the optimal age limit in a particular sport, it is still impossible to deliver an accurate conclusion if a young athlete has potential and capabilities, which may lead him to the achievement of international results. However, it is necessary to identify the worthwhileness of further sports perfection and determine its direction, to orient the athlete's further preparation properly. Solving these problems is only possible on the basis of a comprehensive analysis, which should include neuroregulatory, morphological, functional, and mental peculiarities of young athletes, their adaptive capabilities, their response to training and competitive loads, their ability to learn and improve new techniques, etc. One should also bear in mind that one-time (cross-sectional) testing of children in basic anthropometric (body length, body weight, etc.) and functional $\left(\mathrm{VO}_{2} \mathrm{max}\right)$ indicators does not allow an objectively forecast of an athlete's prospects [28].

The sports result at this stage of selection cannot act as a criterion of prospectivity. Experience shows that athletes with relatively low results at the beginning of the preliminary basic preparation often turn out to be among the strongest by the end of it and continue their progress in the future. At the same time, champions and medallists of children's and teenage competitions very rarely (less than $5 \%$ of all cases in different sports) achieve sports success at the stage of maximum realization of their individual capabilities. This is convincingly proven by the long-term experience in training top-class athletes in different countries of the world. 
Already at the beginning of the second stage of longterm preparation, there is a need to benchmark the body structure of young athletes to the morphological features of top-class masters. Morphological features are among the most important ones, which must be taken into account when determining prospects of an athlete at this stage of selection. Morphological variances between representatives of different sports are the result of intensive selection, as bodily features often provide an athlete with purely mechanical or biomechanical advantages in competitions in different sports.

It should be kept in mind that for athletes specializing in different sports, the higher the level of their qualification is, the greater is the degree of pronouncement of individual constitutional differences. This is preconditioned by the combined effect of two factors - sports selection as a variety of professional selection and means and methods specific to a particular sport. For example, wrestlers are characterized by a pronounced mesomorphism, which is evaluated at 5-6, and sometimes at 7 points.

In ice hockey, the mesomorphic component is more pronounced in attacking players and defenders than in goalkeepers. Long-distance runners have a manifested ectomorphic component. Shot putters, weightlifters performing in the super heavyweight, often feature a demonstrated endomorphism. Women who specialize in sports games have a much greater degree of mesomorphism as compared with women who do not engage in sports.

To identify the potential of young athletes for speedstrength work or endurance training work associated with aerobic potential, some experts recommend taking a biopsy study of muscle tissue. However, at this stage of long-term preparation, such a procedure should not be undertaken for two reasons: 1) at the age of 11-14 years, the ratio of muscle fibres of different types inherent to adults is not yet fully formed; 2) there is no need for such studies as the percentage of muscle fibres of different types is closely related to functional capabilities of an athlete. In particular, the athlete's high alactic capabilities, prompt motor response, high results in speed and strength tests (for example, a standing vertical jump), and others guarantee the increased number of fast-twitch fibres. And, on the contrary, a slow reaction, high capabilities of the oxygen transportation system and the oxygen utilization system evidence the predominance of slow-twitch fibres in the muscles of an athlete [33, 59].

An analysis of the nervous system properties - the strength of the processes of excitation and inhibition, their balance and mobility - is of great importance for the rational selection and orientation of young athletes at this stage. The strength of nervous processes characterizes the ability of nerve cells to tolerate strong excitation and strong inhibition, which allows a person to respond adequately to various stimuli. A balance implies a certain correlation between the processes of excitation and inhibition, and their mobility is expressed in the ability of the nervous system to rapidly alternate these processes. Different people may feature various combinations of properties of the nervous system, which largely determine not only psychological but also functional capabilities of athletes [5, 20, 82], especially such as the effectiveness of muscular-motor differentiation, the ability of adequate assessment of the functional state, perception of emerging situations, adoption and implementation of creative solutions, etc. $[11,17]$.

When considering athlete's perspectives by his/her somatotype indexes, not only their overall assessment (by the same indicators as in the previous stage of selection) should be carried out, but the athlete should also be oriented to a specialization in a particular distance or discipline. Thus, teenagers of high stature, with long limbs, great strength capabilities of the brachial muscles may be recommended to specialize in the swimming sprint; children with good swimming capabilities and streamlined bodies, high capabilities of the oxygen transportation system, adequate flexibility of ankle joints are recommended for long distances [2].

Teens with the height above the average and long legs, with high speed-strength capabilities of the leg muscles should be oriented to short-distance running; adolescents with a small body weight, long and thin lower limbs and high capabilities of the oxygen transportation system are recommended for long-distances [6, 47, 77, 82].

The assessment of personal and psychological qualities of young athletes acquires an increased importance. By its results, it is recommended to give preference to persistent, confident in their abilities, eager to train with strong partners and compete with strong opponents. A thorough evaluation of an athlete's personality and mental qualities makes it possible to determine the degree of his/her predisposition to short, medium, or long distances. It is taken into account that sprinters are usually characterized by a weak (reactive) type of the nervous system; they are inclined to categorical assertions, high excitability, uncertainty of temper, and, on the contrary, long-distance performers are distinguished by an even good temper, diligence and discipline, weak attentional set-shifting, low emotionality, poor adaptability to new conditions [7]. Such information is useful not only for running, swimming, or speed skating. It is extremely important for sports games and martial arts as it rationally orientates the training process at the definition of an optimal individual model of gaming activities.

At this stage, it is already critical to take into account perceptual abilities, which are extremely important for effective training and competitive activities in any sport. They have a slight relation to age or peculiarities of biological development, and they are mainly conditioned by the variety of training and competition means [37] and, of course, an appropriate mental attitude oriented to perception, analysis, and reproduction of sensations.

Priority aspects of medical control at the second stage of the long-term selection is the detection of latent diseases and nidi of infections in the body since children with direct 
contraindications should be identified already at the primary selection stage. The biological age of athletes should be assessed once again confirming the type of biological maturation determined during the primary selection.

The most important provision of the primary selection is the need to focus not so much on absolute indexes of the level of different qualities and abilities but rather on the rates of their increase, the forecasted significance of which is much more important [13]. In its turn, the progress of a young athlete should be assessed taking into account the rates of his/her biological maturation and the peculiarities of training. Naturally, priority should be given to those who have achieved a significant increase in their preparedness at a low rate of biological maturation, versatile and "sparing" preparation.

The effective organization of the preliminary and subsequent stages of selection is largely based on understanding of the fact that a coach, even the most qualified one, cannot comprehensively assess prospects of trainees on his/her own. It requires involvement of doctors and biologists, modern equipment and specialists who know how to operate it, which includes examinations of athletes not only in the laboratory environment but also in ordinary training conditions.

\section{INTERMEDIATE SELECTION AND ORIENTATION AT THE THIRD STAGE OF LONG-TERM PREPARATION}

The main task of the third stage of selection is to identify athlete's abilities to achieve highest sports results in the chosen sport, endure high training and competitive loads. By this time, it is already necessary to determine, which specific type of competitions an athlete will specialize in, to define his/her strong qualities, which will become the main factors of achieving high sports results. This is prime importance for sports games, which is associated with the choice of the game role and the corresponding orientation of the entire future training system.

An essential part of the selection at this stage is the assessment of techniques of various special preparatory exercises. For example, in complex coordination sports, mastery of basic and specialized elements; quantitative, qualitative, and structural diversity of these elements; artistic impression, elegance, expressiveness, and stability of their performance are assessed. The efficiency of movements in most cyclic sports is confirmed by their low pace at a big step length and high speed of covering short distance segments. Such manner of movements is especially predictive during the selection and training orientation of sprinters, runners, swimmers, and skaters.

The effectiveness of selection is largely related to the assessment of athletes' main indexes that describe the level of their special preparedness and sports mastery. The level of development of physical qualities (speed-strength, various types of endurance, flexibility, and coordination abilities), capabilities of the energy supply system, perfect sports techniques, the economy of performance, the ability to endure workloads and to recover efficiently should always be in the focus of attention of a coach training young athletes.

The assessment of the listed abilities along with sports results should be in the limelight of attention during the selection and orientation of an athlete in the third stage. At the same time, attention should be paid not only to absolute indexes of the training level and sports achievements but also to the rate of their increase from one stage of preparation to the next one.

At the third stage of long-term selection, the value of indexes of personal-psychological qualities: mental reliability, motivation, will, aspiration for leadership, etc. increases. It is a well-known fact that top-class athletes are distinguished by persistence, lack of suspiciousness, and high tolerance to work loads. When a young athlete assessed by his/her compliance with the requirements for top-class athletes, a special attention should be paid to his/her self-confidence, stress tolerance, aptitude and eagerness for sports competitions, desire to train and compete with strong partners and opponents. Personal and mental qualities of an athlete not only set the criteria for assessing prospects but also additional criteria for assessment of predisposition to specialization in different sports. Athletes inclined to achievements in sprint, speed-strength sports, and leadership in sports games usually have a weak (reactive) nervous system. At the same time, categorical assertions, high excitability, emotional instability, easy adaptation to new living and training conditions, quick transition from sleep to wakefulness, quick mastery of skills, low concentration of attention, and the need of using special methods for its activation are the main indicators of their behaviour. Athletes who are inclined to achievements in sports that require great endurance (for example, cyclists-road racers, long distance runners, etc.) are known for their calm and stable temper, diligence and discipline, poor adaptation to new conditions. They feature a reduced sensitivity to stimuli, a high concentration of attention, an objective evaluation of their potential, persistence and determination, weak attentional set-shifting, low emotionality.

Much attention is paid to medical control during the intermediate selection as during the primary selection. By this time, "screening-out" of children with apparent contraindications to sports has already occurred, specific attention is paid to detection of latent diseases, in particular nidi of infections in the body. If any of them get activated during training sessions, various exacerbations and complications may affect the internal organs. It is also important to detect specific diseases inherent to those engaged in a particular sport.

A fundamental part of the selection is to carry out a comprehensive analysis of the previous training periods, establishing factors, which helped a young athlete achieve his/her level of preparedness. It's no secret that many young athletes perform huge amounts of work in the sec- 
ond stage of their long-term preparation, take part in competitions, do exercises with heavy loads, train twice a day and thus achieve results and training levels high for their age. As a rule, athletes who have undergone such training are hopeless for further perfection in the third stage of long-term preparation. Those who have achieved a relatively high level of training and sports results with small and medium volumes of work, limited competitive practice, and versatile technical training should be given preference.

\section{MAIN SELECTION AND ORIENTATION \\ IN THE FOURTH AND FIFTH STAGES OF LONG-TERM PREPARATION}

At this stage of the selection, it is necessary to determine whether an athlete is capable of achieving results of the international class, whether he is able to endure an exceptionally intense training program and adapt effectively to applied loads. Therefore, selection at this stage is a natural continuation of the work carried out at the previous stage. Its efficiency is largely determined by the same factors but with a more specific focus.

Table 6 shows the most common morphological characteristics of top-class athletes specializing in different sports as well as optimal age limits for achieving the highest sports results. These data along with a set of other indexes can help a coach select the most promising athletes, do realistic assessment of potential of his/her trainees, correctly determine the beginning and the end of the fourth stage of long-term preparation as the stage of preparation for the highest achievements. These indexes are approximate, and therefore significant deviations in one direction or another are possible. In particular, the runners who have been successful at the Olympic Games and other major competitions greatly vary in their height.
The height of men who specialize in running distances of $1500 \mathrm{~m}$ ranges from 164 to $186 \mathrm{~cm}, 5000 \mathrm{~m}-169-185 \mathrm{~cm}$, $10,000 \mathrm{~m}-165-185 \mathrm{~cm}$, the marathon run $-175-183 \mathrm{~cm}$. Women have the same tendency: $1500 \mathrm{~m}-154-176 \mathrm{~cm}$, $10,000 \mathrm{~m}$ - 154-172 cm. Different height of athletes determines different running techniques. Long limbs of tall athletes ensure a great amplitude of movements; athletes of short stature usually apply the technique with a high frequency of steps. However, low-height runners often possess a long running step due to their take-off force. Practice testifies that a somatotype of a specific athlete taken into account, the level of development of his/her speedstrength qualities and energy potential contributes to the formation of a rational running technique, which can be mainly determined by the large step length, high frequency of steps, or an optimal combination of these parameters.

Thus, with all the informational value of the body height and weight indexes, they should always be considered in close relationship with parameters of sports techniques, functional capabilities of the most important body systems, and mental characteristics of an athlete. Only in this case, one can draw the right conclusions about the athlete's ability to achieve outstanding results, for example, in the sprint, there are successful athletes of short stature (Murchison) and very tall ones (Williams, Bolt), thin-boned and lightweight (Mennea), strong and heavy (Johnson). In modern tennis, success mostly comes to tall and powerfully built players with long arms (Lendl: height - $188 \mathrm{~cm}$, weight - $79 \mathrm{~kg}$, Becker $-188 \mathrm{~cm}$ and $83 \mathrm{~kg}$, Martin $-198 \mathrm{~cm}$ and $86 \mathrm{~kg}$, Rosset - $201 \mathrm{~cm}$ and $87 \mathrm{~kg}$, Nadal $-185 \mathrm{~cm}$ and $85 \mathrm{~kg}$, Federer - $185 \mathrm{~cm}$ and $85 \mathrm{~kg}$, Murray - $194 \mathrm{~cm}$ and $84 \mathrm{~kg}$, Bryan - $198 \mathrm{~cm}$ and $97 \mathrm{~kg}$ ). However, there are many cases when athletes of relatively low height but possessing high speed qualities and good coordination (Agassi -

TABLE 6 - Optimal age, height, and body weight indexes of athletes specializing in cyclic sports.

\begin{tabular}{|c|c|c|c|c|c|c|}
\hline \multirow{2}{*}{ Sport, distance } & \multicolumn{3}{|c|}{ Men } & \multicolumn{3}{|c|}{ Women } \\
\hline & Age, years & Height, cm & Weight, kg & Age, years & Height, cm & Weight, kg \\
\hline Rowing & $21-25$ & $190-200$ & $90-100$ & $20-23$ & $175-185$ & $65-75$ \\
\hline Canoeing & $21-25$ & $185-195$ & $80-95$ & $20-23$ & $170-80$ & $60-70$ \\
\hline \multicolumn{7}{|l|}{ Swimming: } \\
\hline $100,200 \mathrm{~m}$ & $19-23$ & 185-195 & $80-95$ & $18-22$ & 172-182 & $60-70$ \\
\hline $400,800,1500 \mathrm{~m}$ & $17-21$ & $180-190$ & $80-90$ & $18-22$ & $165-175$ & $50-60$ \\
\hline \multicolumn{7}{|l|}{ Running: } \\
\hline $100,200,400 \mathrm{~m}$ & $22-26$ & $180-190$ & $75-85$ & $20-24$ & $165-175$ & $55-65$ \\
\hline $800,1500 \mathrm{~m}$ & $24-28$ & $172-182$ & $67-77$ & $22-26$ & $160-170$ & $50-60$ \\
\hline $5000,10000 \mathrm{~m}$ & $26-30$ & $170-180$ & $60-70$ & $24-28$ & $158-168$ & $48-56$ \\
\hline \multicolumn{7}{|l|}{ Cycling: } \\
\hline track & $21-25$ & 175-185 & $75-85$ & $19-23$ & $165-175$ & $55-65$ \\
\hline road & $22-26$ & $172-182$ & $67-77$ & $21-25$ & $163-173$ & $52-60$ \\
\hline Speed skating & $22-26$ & $172-182$ & $70-80$ & $20-24$ & $162-172$ & $55-65$ \\
\hline Cross-country skiing & $22-26$ & $170-180$ & $63-73$ & $22-26$ & $160-170$ & $53-63$ \\
\hline
\end{tabular}


$178 \mathrm{~cm}$ and $70 \mathrm{~kg}$, Chang - $173 \mathrm{~cm}$ and $61 \mathrm{~kg}$ ) achieved very high results. The same situation exists in women's tennis, where tall athletes achieve success (Williams $185 \mathrm{~cm}$, Sharapova - $188 \mathrm{~cm}$, Azarenka - $183 \mathrm{~cm}$, and so on) alongside with tennis players of relatively low stature (Hénin - $167 \mathrm{~cm}$, Tarabini - $165 \mathrm{~cm}$, Zvonareva - $169 \mathrm{~cm}$, and others).

It is truly interesting to analyse the body composition of athletes specializing in different sports. Peculiarities of different sports influence the composition of athletes' bodies to a great extent. It is possible to notice this already when studying low-fat mass and fatty tissue of top-class athletes. Long-distance runners, wrestlers, and boxers (except for absolute weight classes), road racers, skiers have an exceptionally low percentage of fat - typically ranging from 4 to $8 \%$. Volleyball, basketball, and tennis players retain the percentage of fat usually at $14-17 \%$, and throwers - at $18-22 \%$. The amount of fat in women's bodies is usually $6-10 \%$ higher than in those of men $[60,66]$.

Significant differences in the body structure of outstanding athletes should induce the search for different ways of reaching the pinnacles of sportsmanship. This applies both to the development of individual models of technical and tactical skill formation and functional readiness as well as to the formation of an individual training system for each prospective athlete at all stages of his/her long-term perfection, especially at the stage of the maximum realization of his/her individual abilities, when a unique model of competitive activities is being formed.

It should be remembered that peculiarities of each sport, main trends in the development of techniques and tactics, the improvement of rules, and so on exert a significant impact on shaping of requirements for morphological characteristics of athletes. So, for example, modern handball sets forth high demands to the height of athletes and their athletic preparation; that is why, the strongest handball players of the world are very tall (many of them are above $195-200 \mathrm{~cm}$ ) with a large body weight of $90-110 \mathrm{~kg}$. The same requirements for morphological characteristics of athletes exist in modern volleyball. On the contrary, in ice hockey and water polo, the exceptional dynamism of these games set by the rules of the competitions gives certain preferences to players who are not that tall but are capable of a high special performance.

When training starts at the fourth stage of long-term preparation, it is necessary to assess thoroughly the level of general and special preparedness of athletes. At this point, attention should be paid not only to absolute indexes but also to the progress that an athlete achieved in training at the previous stage (Table 13). Preference should be given to those athletes who demonstrate great changes in the level of sports mastery, the capabilities of the most important functional systems with the limited application of the most powerful pedagogical instruments; the less effort was applied to achieve progress in sports mastery, the greater reserves remained for further improvement.
Therefore, at this stage of selection, special attention is paid to the analysis of training at the previous stage of long-term preparation. Athletes who have trained in different programs without resorting to the maximum level of training activities, limited the number of training sessions with extreme workloads, participated in selected competitions, i.e. have not reached the maximum levels of training and competitive loads typical for training sessions at the stage of the maximum implementation of individual capabilities. If the levels of their achievements and functional preparedness have been systematically growing in such a training process, and they have reached a fairly high level of sports skill by the fourth stage of their long-term preparation, then there is every reason to believe in their further serious advancement.

Of particular importance is the assessment of personal and mental qualities of an athlete. In this assessment, they evaluate stress tolerance in competitions, the ability to perform intensive and high-quality work in conditions of extreme fatigue, the ability to set oneself up for an active competition and muster all strengths in acute competition, the mental stability in performing voluminous and intense training work, the ability to control efforts, speed, direction of movements, distribution of strengths in competitions as well as the ability to achieve the highest results in the most important events surrounded by strong competitors. As a rule, outstanding athletes possess the ability to engage in an active struggle in the most important events with the toughest competition. It is not without reason that experienced coaches use the ability to achieve higher results in the final events than in the preliminary rounds as one of the most important criteria for assessing the prospects of athletes. Experience shows that mental stability, the ability to mobilize to the maximum in the extreme conditions of significant competitions are largely determined by the innate potential and can improved only with great effort.

The selection for team disciplines in cycling and rowing, sports games has its own peculiarities. For instance, in team track and road racing during, selection is often based on the relative similarity of the anthropometric parameters of the teammates; their ability to effectively maintain the race in the leading position, the level of team race technique, and the effective finish. Racers somewhat inferior in their skill to their team mates during individual events are often selected for team events as the ones having more advanced characteristics for the team competition. Often, the ability of an athlete to sacrifice his/her benefits for the sake of a teammate led our racers to brilliant victories during the World Championships and the Olympic Games.

Even more complex problems have to be tackled when teams are formed for sports games. Here, along with individual capabilities of players, the selection into a team is influenced by the tactical variant adopted by the team, peculiarities of the tactics and techniques of the opposing team. Equally important is the ability of each player to adequately assess the capabilities of partners and his/her 
own, to subdue aspiration for personal success for the sake of his/her team. So, a team is being formed, one should pay attention to how the capabilities of individual players match their player roles within the team, the type of functions and tasks assigned to them.

For many athletes, training and competitive activities in the fourth and fifth stages cover a very long period - up to 10-12 years or more. In the course of this time period, the contents of training and peculiarities of its orientation vary significantly among athletes who have reached a high level of skill and those who have significantly exhausted their functional capabilities. Therefore, the orientation process should be preceded by a constant and comprehensive study of the athlete's capabilities, his/her individual characteristics, the structure of competitive activities, and other to find reserves to increase and maintain the level of adaptation, optimize the structure of competitive activities, constant perfection of the model that agrees with the strongest individual qualities of a swimmer. The above is often complemented by the orientation of mature athletes to a very narrow specialization. In particular, a fair number of examples show that swimmers who had successfully performed at distances of 50, 100, and $200 \mathrm{~m}$ for a number of years, limited their specialization to the 50-metre distance with age, which allowed them to reduce volumes of their training work two- or three-fold and dramatically increase their performance period at the level of the highest achievements. Athletes who specialize in rowing and have achieved outstanding results may still remain competitive with younger opponents competing in single- and twin-seater boats. However, they often keep up a successful career as team members of eight-seater boats.

Selection at this stage implies solving specific issues related to recruitment for national teams. A rational organization is possible with collective decision-making on the enrolment of athletes into the national team for targeted preparation for specific major competitions involving not only coaches and team managers but also doctors and members of a complex group of professionals responsible for scientific and methodological backgrounds of training. The following schedule of team staffing for targeted preparation for specific major competitions is recommended: three years before competitions - selection of a wide range of candidates; two years before competitions - reforming and "narrowing" the line-up; one year before competitions - a radical cut in order to select only true contenders for places in the finals; four months before competition - a preliminary and two months before them - a final draft with those athletes, whose skills are adequate to those of the potential finalists: mental integrity, the need for achievement, the absence of health conditions that may militate against success.

If a national team for the main competitions (World Championships, the Olympic Games) is formed too late, this will prevent the strongest athletes from a proper design and completion of preparation for the main events, the duration of which cannot be less than 6-8 weeks. [9].
An indispensable prerequisite for successful perfection in the fourth stage of long-term preparation is the athlete's strong health. Prior to the assessment of the athlete's capability of attaining the highest results, one needs to make sure that he/her has no diseases or conditions that may hinder his/her performance and to quickly fix minor deviations in his/her health.

\section{FINAL SELECTION AND ORIENTATION AT THE SIXTH AND SEVENTH STAGES OF LONG-TERM PREPARATION}

The final selection is an extremely important part of the preparation system, since its main task is to determine whether a top-class athlete who has achieved significant results in sports should continue his sports activities. The accuracy and objectiveness of this assessment will not only have a significant impact on the sports career of a well-known athlete, his/her authority in sports but also on his/her whole future life - education, personal life, professional career, etc.

At this stage of selection, the assessment of the athlete's prospects in terms of his/her morphological and functional potential, his/her aptitude for effective perfection, etc. are not relevant. At this point, the top priority task is to identify reserve capabilities of the body for maintaining and possibly increasing the previously reached level of adaptation. Not least important is a comprehensive medical examination, which should show whether an athlete is capable of further strenuous work, whether the injuries previously sustained can seriously affect future training and competitive activities.

A comprehensive analysis of the athlete's social status - his/her financial situation, educational background, prospects for successful activities after retirement from sports, family well-being, etc. is of paramount importance. If at the previous stages of selection adolescent and young athletes studying at secondary schools or higher educational institutions did not face such problems, for the athletes, whose age is above $25-30$ years, they may become of primary concern.

Reviewing sports-pedagogical aspects of selection, attention should be paid to the length of the sports career, the amount of training and competitive loads endured over many years of preparation. Naturally, the shorter was the period of previous sports activities, the lower were the training and competitive loads, the greater are the prospects - all other conditions being equal - for an athlete to maintain the level of the highest achievements.

The assessment of the structure of the athlete's functional preparedness, available reserves for the improvement of the most important components are also important. For instance, athletes who have a high capacity of the most important functional systems and reserves for improvement of the technique economy, mobility and variability of energy supply systems have sufficient reserves to maintain their highest achievements and even to improve their sports performance. 
At the final stage of selection, the assessment of the athlete's mental qualities has its own peculiarities. At the previous stage, the main focus was on the ability of an athlete to mobilize his/her capabilities in the extreme conditions of significant competitions, the ability to achieve the highest results in the main competitions, the detection of strong opponents, etc.; at this stage, it is the motivation for actively continued sports activities, endurance of high training and competitive loads is of utmost importance.

Considering orientation issues of the athlete's preparation at the stage of maintaining world-class level of perfor- mance, the qualitative characteristics of the preparation process need to be brought to the forefront. The experience of training many outstanding athletes in different countries of the world convincingly proves that the athletes who had been able to find reserves for maintaining sports results with simultaneous reduction in the volume of training and competitive activities were able to maintain their highest achievements.

Athletes who had attempted to maintain the highest achievements through the extreme training and competitive loads failed and had to quit elite sports with injuries, physical and mental overwork.

\section{Питература}

1. Бубка СН, Булатова ММ, Есентаев ТК, Платонов ВН, ред. Менеджмент подготовки спортсменов к Олимпийским играм [Management of training athletes for the Olympic Games]. Киев: Олимпийская литература; 2017.480 c.

2. Булатова ММ. Теоретико-методические основы реализации функциональных резервов спортсменов в тренировочной и соревновательной деятельности [Theoretical and methodological foundations for realization of functional reserves of athletes in training and competitive activities] [автореферат]. Киев; $1996.50 \mathrm{C}$

3. Булгакова НЖ. Отбор и подготовка юных пловцов [Selection and preparation of young swimmers]. Москва: Физкультура и спорт; 1986. 192 с.

4. Булгакова НЖ. Проблема отбора в процессе многолетней тренировки (на материале плавания) [The problem of selection in the process of multi-year training (based on swimming)] [диссертация]. Москва; 1976. $640 \mathrm{C}$.

5. Волков ВМ, Филин ВП. Спортивный отбор [Sports selection]. Москва: Физкультура и спорт; 1983. 176 C.

6. Волков ЛВ. Система управления развитием физических способностей детей школьного возраста в процессе занятий физической культурой и спортом [The system of managing physical capabilities of school children in the course of physical education and sports sessions] [автореферат]. МосКва: ГЦОЛИФК; 1989.38 c.

7. Горбунов ГД. Психопедагогика сnорта [Psychopedagogy of sports]. Москва: Физкультура и спорт; 1986. 208 c.

8. Платонов ВН. Периодизация спортивной тренировки. Общая теория и ее практическое применение [Periodization of sports training. the general theory and its practical applications]. Киев: Олимпийская литература; 2013.624 с

9. Платонов ВН. Система подготовки спортсменов в олимпийском спорте. 06щая теория и ее практическое применение [The system of training athletes in the Olympic sport. The general theory and its practical applications]: учебник для студентов вузов физического воспитания и спорта. Киев: Олимпийская литература; 2004.808 c

10. Платонов ВН. Система подготовки спортсменов в олимпийском спорте. 06щая теория и ее практические приложения [The system of training athletes in the Olympic sport. General theory and its practical applications]. Киев: Олимпийская литература; 2015. Кн. 1.; 680 c

11.Родионов АВ. Психология физического воспитания и сnорта [Psychology of physical education and sports]. Москва: Фонд Мир; $2004.571 \mathrm{C}$.

12.Росс УД, Марфелл-Джонс МД. Кинантропометрия [Kinanthropometry]. В кн.: Физиологическое тестирование спортсмена высокого класса [Physiological Testing of a High-Class Athlete]. Киев: Олимпийская литература; 1998. с. 235-320.

13. Сирис ПЗ, Гайдарска ПМ, Ранее КИ. Отбор и прогнозирование способностей в легкой атлетике [Selection and forecasting talents in athletics]. Москва: Физкультура и спорт; 1983. $103 \mathrm{C}$

14. Сологуб ЕБ, Таймазов ВА. Спортивная генетика [Athletic genetics]. Москва: ТерраСпорт; 2000. 127 с

15. Соха Т. Женский спорт [Female sports]. В кн.: Теория и практика физической культуpы [Theory and Practice of Physical Culture]; 2002. $202 \mathrm{C}$.

16. Теплов БМ. Способности и одаренность [Capabilities and talent]. В кн.: Психология индивидуальных различий [Psychology of individual differences]. 1-е изд. Москва: Издательство Московского института; 1982. с. 133-6.

17. Уэйнберг РС, Гоулд Д. Основы психологии спорта и физической культуры [Foundations of sport and exercise psychology]. [пер. с англ]. Киев: Олимпийская литература; 2001. 336 c.

18. Abbort Abbott A, Collins D. Eliminating the dichotomy between theory and practice in talent identification and development: Considering the role of psychology. J. Sports Sci. 2004:22:395-408.

19. Ama PF, Simoneau JA, Boulay MR, et al. Skeletal muscle characteristics in sedentary Black and Caucasian males. J. Appl. Physiol. 1986;61:1758-61.

20.Arnot R, Gaines C. Tratado de la actividad fisica. Seleccione su deporte. Barcelona: Paidotribo; $1992.453 \mathrm{p}$.

21.Baker J, Cobley S, Schorer J, editors. Talent identification and development in sport: International perspectives. London; New York: Routledge; 2012. $179 \mathrm{p}$

22. Bielen EC, Fagard RH, Amery AK. Inheritance of acute cardiac changes during bicycle exercise: an echocardiographic study in twins. Med. Sci. Sports Exerc. 1991;23:1254-9.

23.Bouchard C, Malina RM, Perusse L. Genetics of fitness and physical performance. Champaign, L: Human Kinetics; 1997.

24. Bouchard C. Genetic determinants of endurance performance. In: Shephard R, Åstrand PO, editors. Endurance in Sport. Blackwell Sci. Publ.; 1992. p. 149-59.

25. Breitbach S. Talentidentifikation in Sport: Chancen und Probleme der Sichtung, genetischen Selektion und molekularen Diagnostik. Leistungssport. 2011;3:9-13.

26. Carlile F. Selected Topics on Swimming Research. In: Swimming into the 21st century. Champaign: Human Kinetics; 1992. p. 153-83.

27. Cobley S, Cooke C. Talent identification and development: An overview of research and practice. In: Paper presented in the Carnegie Seminar Series, Carnegie Faculty. Leeds: Leeds Metropolitan University; 2009.

28. Cobley S, Schorer J, Baker J. Identification and development of sport talent: a brief introduction to a growing field of research and practice. In: Baker J, Cobley S, Schorer J, editors. Talent identification and development in sport: International perspectives. London; New York: Routledge; 2012. p. 1-10.

29. Côté J, Macdonald DJ, Baker J, Abernethy B. When "where" is more important then than "when": Birthplace and birthdate effect on achievement of sporting expertise. J. Sport Sci. 2006;24(10):1065-73.

30. Dai Q. Zhongguo tiyu yexu yige xinshidai [Chinese sport needs a new era]. Xinwen zhpukan [Chinese News Weekly]. 2004;7:9.

31.Davids K, Button C, Bennett S. Dynamics of skill acquisition: A Constraints-led approach. Champaign, IL: Human Kinetics; 2008.

32.De Garay AL, Levine L, Carter J. Genetic and anthropological studies of Olympic athletes. New York: Acad. Press; 1974.382 p.

33.De Vries HA, Housh TI. Physiology of exercise. Madison Wisconsin: WCB Brown and Benchmark Publ.; 1994.636 p.

34.Delorme N, Raspaud M. The relative age effect in young French basketball players: A study on the whole population. Scand. J. Med. Sci. Sports. 2009;19:235-42.

35. Diamond D. Total hockey. New York: Total Sports Publishing; 2000.

36. Diskhuth HH. Genetik und grenzen der menschlichen Leistungsfahigkeit. Leistungssport. 2004; $1: 5-11$.

37.Farrow D. Identifying and developing skill expertise: Understanding current limits and exploring future possibilities. In: Baker J, Cobley S, Schorer J, editors. Talent identification 
and development in sport: International perspectives. London; New York: Routledge; 2012 p. 51-63.

38. Fox E, Bowers R, Foss M, Fox E. The physiological basis for exercise and sport. Madison, Wis. Brown \& Benchmark Publishers; 1993.710 p.

39. Frohner G, Wagner K. Anwendungsorientierungen der Anthropometrie in der Betreuung von Sportlern. Leistungssport. 1996:2:12-6.

40.Frohner G, Wagner K. Korperbau und Sport unter Beachtung des Korpergewichts. Leistungssport. 2002:1:33-40.

41. Gulbin J, Ackland T. Talent identification and profiling. In: Ackland T, Elliott B, Bloomfield J, editors. Applied anatomy and biomechanics in sport. Champaign IL: Human Kinetics; 2008. p. 11-26.

42. Gulbin J. Applying talent identification programs at a system-wide level: the evolution of Australia's national program. In: Baker J, Cobley S, Schorer J, editors. Talent identification and development in sport:International perspectives. London, New-York: Routledge; 2012. p. 147-65.

43. Hamel P, Simoneau JA, Lortie G, et al. Heredity and muscle adaptation to endurance training. Med. Sci. Sports Exerc. 1986;18:690-6.

44. Hamilton B. East African running dominance: what is behind it? Brit. J. Sports Med 2000;34:391-4

45. Hong F.China United States. In: Houlihan B, Green M, editors. Comparative Elite Sport Development: systems, structures and public policy. Oxford: Butterworth-Heinemann; 2008. p. $26-52$.

46. Kunze D, Hughes PCR, Tanner JM. Anthropometrische Untersuchungen an Sportlern der XX. Olympischen Spiele 1972 in München. In: Sportwissenschaftliche Untersuchungen während der XX Olympischen Spiele München; 1972. Gräfelfing; 1972. s. 33-56.

47.Larsen H. Kenyan dominance in distance running. Comp. Biochem. Physiol. A Mol. Integr. Physiol. 2003;136:161-70

48. Lesage $R$, at al. Familial resemblance in maximal heart rate, blood lactate and aerobic power. Hum. Hered. 1985;35:182-9.

49. Major JA, McNeal JR, Sands WA. Physician compliance with physical examinations for national talent-selected female gymnasts age 6-11 years. Proceedings of the North American Society for Pediatric Exercise Medicine. 1996;1:70.

50. Marcotte M, Chagnon M, Cote C, et al. Lack of genetic polymorphism in human skeletal muscle enzymes of the tri-carboxylic acid cycle. Hum. Genetics. 1987;77:200.

51. Meylan C, Cronin JB. Talent identification. In: Lloyd RS, Oliver JL, editors. Strength and conditioning for young athletes: Science and application. London, New York: Routledge; 2014. p. 19-32.

52. Montgomery AB, Mills $Y$, Luse $Y M$. Incidence of acute mountain sickness at intermediate altitude. J. Am. Med. Association. 2002;261:732-26.

53. Morrison EY, Cooper PD. Some biomedical mechanisms in athletic prowess. West Indian Medical J. 2006;55:205-9

54. Musch J, Grondin S. Unequal competition as an impediment to personal development: A review of the relative age effect in sport. Dev. Rev. 2001;21:147-67.

55. Onywera V0, Scott RA, Boit MK, et al. Demographic characteristics of elite Kenyan endurance runners. J. Sports Sci. 2006;24:415-22

56.Perusse L, Garnon J, Province MA, et al. Familial aggregation of submaximal aerobic performance in the HERITAGE Family Study. Med. Sci. Sports Exerc. 2001;33:597-604.

57.Phillips SM, Turner AP, Gray S, et al. Ingesting a $6 \%$ carbohydrate-electrolyte solution improves endurance capacity, but not sprint performance, during intermittent, high-intensity shuttle running in adolescent team games players aged 12-14 years. Eur. J. Appl. Physiol. 2010;109:811-21.

58. Pitsiladis Y. Explaining African dominance in running. In: Baker J, Cobley S, Schorer J, editors. Talent identification and development in sport: International perspectives. London, New York: Routledge; 2012. p. 130-46.

59.Platonov VN. Adaptacion en el deporte. Barcelona: Paidotribo; 1991. p. 11-30.

60.Pollock ML, Jackson AS. Research progress in validation of clinical methods of assessing body composition. Med. Sci. Sports Exerc. 1984;16:606-13.

\section{Автор для корреспонденции:}

Платонов Владимир Николаевич - д-р пед. наук, проф., кафедра истории и теории олимпийского спорта, Национальный университет физического воспитания и спорта Украины; Украина, 03150, Киев, ул. Физкультуры, 1;

https://orcid.org/0000-0002-6994-9084;

vladimir@platonov.org.ua
61. Rankinen T, Bouchard C, Rao DC. Corrigendum: Familial resemblance for muscle phenotypes: The HERITAGE family study. Med. Sci. Sports Exerc. 2005:37:2017.

62. Rankinen T, Perusse L, Rauramaa R, et al. The human gene map for performance and healthrelated fitness phenotypes: the 2001 update. Med. Sci. Sports Exerc. 2002;34:1219-33.

63. Renshaw I, Davids K, Phillips E. Developing talent in athletes as complex neurobiological systems. In: Baker J, Cobley S, Schorer J, editors. Talent identification and development in sport: International perspectives. London, New York: Routledge; 2012. p. 64-80.

64. Rice T, Despres JP, Perusse L, et al. Familial aggregation of blood lipid response to exercise training in the health, risk factors, exercise training and genetics (HERITAGE) Family Study. Circulation. 2002:82:1904-8.

65. Rico-Sanz J, Rankinen T, Joanisse DR, et al. Familial resemblance for muscle phenotypes in the HERITAGE Family study. Med. Sci. Sports Exerc. 2003:1360-6.

66. Robergs RA, Roberts SO. Fisiologia do Exercicio. Sao Paulo: Phorte Editora; 2002. 490 p.

67. Robinson P. Jamaican athletics: A model for the world. Kingston: Marco Printers Ltd.; 2007.

68. Saltin B, Kim CK, Terrados N, et al. Morphology, enzyme activities and buffer capacity in leg muscles of Kenyan and Scandinavian runners. Scand. J. Med. Sci. Sports. 1995;5:222-30.

69. Sands RR, Sands LR. The anthropology of sport and human movement: a biocultural perspective. Lexington Books; 2012. 353 p.

70. Sands WA. Talent identification and development in women's artistic gymnastics: the Talent Opportunity Program (TOPs). In: Baker J, Cobley S, Schorer J, editors. Talent identification and development in sport: International perspectives. London, New York: Routledge; 2012. p. 83-94.

71.Sands WA. Talent opportunity program. Indianapolis, IN: United States Gymnastics Federation; 1993

72.Schorer J, Büsch D, Fischer L, et al. Back to the future: a case report of the ongoing evaluation of the German handball talent selection and development system. In: Baker J, Cobley S, Schorer J, editors. Talent identification and development in sport: International perspectives. London, New York: Routledge; 2012. p. 119-29.

73.Scott RA, Georgiades E, Wilson RH, et al. Demographic characteristics of elite Ethiopian endurance runners. Med. Sci. Sports Exerc. 2003;35:1727-31.

74.Scott RA, Pitsiladis YP. Genotypes and distance running: Clues from Africa. Sports Med. 2007;37:1-4.

75. Tenner JM. The physique of the Olympic athlete. London: George Alien and Unwin Ltd. 1964. $126 \mathrm{p}$.

76. Timmons JA, Knudsen S, Rankinen T, et al. Using molecular classification to predict gains in maximal aerobic capacity following endurance exercise training in humans. J. Appl. Physiol. 2010;108:1487-96

77. Tittel K, Wutscherk H. Anthropometric factors. In: Strength and power in sport. Blackwell Sci. Publ.; 1991. p. 180-96

78. Tittel K, Wutscherk H. Anatomical and anthropometric fundamentals of endurance. In: Shephard R, Åstrand PO, editors. Endurance in sport. Blackwell Sci. Publ.; 1992. p. 35-45.

79. Vaeyens $R$, Güllich A, Warr $C R$, et al. Talent identification and promotion programmes of Olympic athletes. Journal of Sports Sciences. 2009;27:1367-80.

80. Wells G, Schneiderman-Walker J, Plyley M. Normal physiological characteristics of elite swimmers. Pediatric Exercise Science. 2006;17:30-52.

81. Weston AR, Karamizrak 0, Smith A, et al. African runners exhibit greater fatigue resistance, lower lactate accumulation, and higher oxidative enzyme activity. J. Appl. Physiol. 1999:86:915-23.

82. Wilmore JH, Costill D, Kenney WL. Physiology of sport and exercise. 4th ed. Human Kinetics; $2009.529 p$

83. Wutscherk H, Schmidt H, Schuke S. Zur Beurteilung der Korpermasse bei Kindern und Jugendlichen. Med. Sport. 1988;28:177.

84. Wutscherk H. Grundzuge der Methodologie der Sportanthropometrie [dissertation]. University of Leipzig; 1977

\section{Corresponding author:}

Platonov Vladimir - Dr. Sc. in Pedagogy, prof., department of History and Theory of Olympic Sports, National University of Ukraine on Physical Education and Sport Ukraine, 03150, Kyiv, 1, Fizkultury Str.;

https://orcid.org/0000-0002-6994-9084

vladimir@platonov.org.ua 